\title{
Factors Affecting the Implementation of Health and Safety in Supermarkets in Kenya
}

\author{
Kaaria Ann Gaceri \\ Research Student, Nairobi Central Business District Campus \\ Jomo Kenyatta University of Agriculture and Technology \\ Corresponding email: tchamicurtis@yahoo.co.uk
}

Doi:10.5296/ ijhrs.v5i2.7839 URL: http://dx.doi.org/10.5296/ ijhrs.v5i2.7839

\begin{abstract}
In today's rapidly changing commercial world 'retail design' is taking on the great importance than ever before both in terms of selling a company's products and promoting an organizations' corporate identity (Onwong'a, Mamati, Kangu \& Osongo, 2010). The purpose of this study was to evaluate the factors affecting the implementation of health and safety measures in supermarkets in Kenya; A survey of Supermarkets in Kenya. The implementation of health and safety measures at workplaces is minimal and yet it goes without doubt that if properly implemented, workplace accidents, injuries and illness would decrease in number. The research study was thus to facilitate the understanding of the benefit to implementing health and safety measures, thereby enhancing the acceptance in organizations.

The study was be guided by the following specific objectives, to establish whether leadership influences the implementation of health and safety measures in supermarkets in Kenya, to find out whether employee training influences the implementation of health and safety measures in supermarkets on Kenya, and to establish whether employee participation influences the implementation of health and safety measures in supermarkets in Kenya. The study employed a descriptive research design (Sekaran, 2006).Data analysis was aided by SPSS Version 17(Marija, 2008). The target population was the general retail merchandise in Kenya while the study population was Human Resource Department Staff in supermarkets with more than 10 outlets in Kenya. The study was a census of supermarkets with more than 10 outlets and hence the sample size was equal to the study population.

Primary data was collected using self administered questionnaires. A pilot test was conducted to test the validity and reliability of the research instruments. The study employed descriptive statistics and data analysis was performed using both qualitative and quantitative techniques.

The final findings were presented using pie charts and statistical tables. This study will be of value to the human resource managers of the general retail merchandise industry, the government, research institutions, scholars and other private institutions.
\end{abstract}


Keywords: Supermarkets, Health, Safety, Retail Marketing

\section{Introduction}

The chapter introduces the background of the study, statement of the problem, and general and specific objectives. It also covers the research questions, justification, scope and limitations of the study.

\subsection{Background of the study}

According to Bratton \& Gold (2009), the World Health Organization (WHO), defines," Health as a state of complete physical, mental and social wellbeing, not merely an absence of disease and infirmity '.According to this definition, managers are immersed in one of society's greatest challenges - the design and maintenance of a work organization that both supports the organizations objectives and provides an environment that is safe and healthy for its employees. Occupational Health and safety encapsulate quite distinct yet intrinsically related concepts concerned with the identification and control of work induced ill - health is largely invisible and can develop over a long period of time, for example asbestosis (Cullen,2002).

The Health and Safety Commission and the Department of the environment, Transport and the regions (HSC/DETR 2000), document made the business case for health and safety at workplace: In considering the economics of an unhealthy and unsafe workplace, it is necessary to distinguish between costs failing upon the organization and costs falling upon government funded bodies such as hospitals.(Bratton \& Gold,2009).It is not difficult for an organization to calculate the economic costs of a work related to lost production due to an accident and illness, there are also indirect costs. A safe and health work environment can reduce operating costs and improve organizational effectiveness. It has been long argued that an investment in health and wellness improves worker commitment and performance (Mearn \& Hope, 2005), thus, top management should approach Health and Wellness as an investment rather than a cost. (Dyck, 2002).

According to Dessler (2008), occupational health and safety act (OSHA) operates under the "general standard clause that each employer .....Shall furnish to each of his( or her) employees employment which are free from recognized hazards that are causing or are likely to cause death or serious physical harm to his (or her) employees". To carry out the basic mission, OSHA is responsible for promulgating legally enforceable standards. These are contained in five volumes covering general industry standards, maritime standards, construction standards, other regulations and procedures, field operations manual(Hammer \& Price,2001).

According to Occupational Safety and Health Act (2007), the act applies to all workplaces where any person is at work temporarily or permanently. The purpose of this act is to secure the safety, health and welfare of persons at work, and protect persons at work against risks to safety and health arising out of, or in connection with the activities of persons at work. For the purpose of providing practical guidance with respect to any provision of this Act and of 
safety and health regulations, the director shall, in consultation with the council, approve and issue codes of practice, which are in his opinion suitable for that purpose. Every occupier shall ensure the safety, health and welfare at work of all persons working in his workplace. Without prejudice to the generality of an occupier's duty under subsection (1), the duty of the occupier includes, the provision and maintenance of plant and systems and procedures of work that are safe and without risks to health.

However the Kenyan minister for labour, Munyes John .K , during the world day for safety and health at work 2011, April 28, said that since the adoption of the global strategy on occupational safety and health by ILO (International Labour Organization), in 2003 which emphasized the establishment of national preventative safety and health culture and the introduction of a systems approach in the management of occupational health and safety in member countries, Kenya has a remarkable progress in this regard (The Standard Newspaper,2011 April 28).

In collaboration with relevant stakeholders, Kenya has domesticated Occupational health and safety management systems and the implementation of the strategy. A systems approach was introduced in the occupational safety and health act( 2007), which demands formation of safety committees and training of their members, enterprise risk assessment, and medical examination of workers, periodic testing and examination of hazardous equipment and annual audit at workplace (The standard newspaper, 2011 April 28 ).

According to Armstrong (2009), written health and safety policies are required to demonstrate that top management is concerned about the protection of the organization's employees from hazards at work and to indicate how this protection will be provided . They are therefore first, a declaration of intent, second, a definition of the means by which that intent will be realized, and third, a statement of the guidelines that should be followed by everyone concerned, which means all employees ,in implementing the policy .The policy should consist of three parts: the general policy statement ,the description of the organization for health and safety, details of arrangement for implementing the policy (Dohery \& Tyson ,2000).

Effectively managing workplace safety and health requires far more than reducing the number of job related accidents and injuries. In practice, legal and ethical issues, many of which involve a careful balancing of individual rights (particularly the right of privacy).with the needs of the organisation, because these issues often give rise to legal questions.HR professionals are frequently called upon to develop and implement policies to deal with them. Among the weightiest issues, facing employers today are dealing with HIV/AIDS in the workplace, workplace violence, smoking in workplace, cumulative trauma disorders, hearing impairment, foetal protection, hazardous chemicals, and genetic testing. It is important to recognise that in addition to these direct challenges, there is also the challenge of employees' commitment to safety and health programs. (Balkin, Cardy, \& Mejia, 2007).

According to Price (2004), the relationship between work and health may appear substantial but it is viewed in different ways by different groups of people. One of the defining characteristics of the workplace setting is that it brings together a variety of groups who have 
different agendas with regard to work or health. The key parties are workers or employees and their trade unions or staff associations, employers and managers, occupational health staff, health and safety officers, environmental health officers and specialist health promoters.

According to Dessler (2008), OSHA primary responsibility for enforcing OSHA, It develops occupational standards, grants variances to employers, and conducts workplace inspections and issues citations and penalties. Example of development of standards is OSHA'S proposed National ergonomics standards. The national institute for occupational safety and health reported in 1997 that musculoskeletal disorders related to the neck shoulders, elbow, hand, whist and back generated at least and 13 million a year in workers, compensation costs.

Health and safety are workplace issues with considerable organisational and legal implications for Human resources and other managers. Naido and Wills (2000), identify the benefits to organisations from the promotion of health in the workplace as (a)" hard" benefits such improvements in productivity as a result of reduced sickness, absence and staff turnover and (b) "soft" benefits including enhanced corporate image (Price ,2004).

\subsubsection{Supermarkets in Kenya}

According to Kibwage, Odondo \& Momanyi (2008), the formal retail market of Kenya comprises numerous supermarkets. In East Africa, Kenya's supermarkets industry is the most developed and rapidly expanding with an annual growth rate of $18 \%$. ( Neven \& Reardon, 2004).The major supermarkets are Uchumi supermarkets limited ,Tuskys Supermarkets and Nakumatt holdings limited. According to Ngugi \& Nyoro (2007), in 2004, there were 204 supermarkets outlets in Kenya and there were 11 hypermarkets (Neven \& Reardon, 2004), up from 200 supermarkets and 10 hypermarkets respectively in 2000, (Stamoulis, 2003).According to Kimutai (2007), Nakumatt Holdings Limited, a Kenyan supermarket chain has made the prestigious planet retail top 30 global retail listing the chain made position 25 in the planet retail top 30 grocery retailers in Africa and the Middle East, 2006 rankings. Supermarkets have spread from the capital to intermediate and small towns, with $44 \%$ of supermarkets sales and 58\% of supermarkets being located outside of Nairobi in 2003 (Neven \& Reardon, 2005).Tuskys, the second largest retailer in the country, operates supermarkets and has been able to seal any gaps left by Nakumatt Holdings Limited. The retailer recently rebranded from Tusker Mattresss to Tuskys, a sign of the company's transformation from a family business to a corporate entity.

Due to popular demand and the lack of land available in the capital for large sized stores, Tusky has been forced to relocate some of its stores in Nairobi and the retailer is currently expanding its network into the suburban districts such as Thika,Athi river and Rongai (Kamau \& Diaby,2008). Uchumi Supermarkets limited has more than 10 outlets and has plans of expanding to other East African countries, although it has been undergoing financial problems and recently the shareholders having been fighting for its relisting into the Nairobi Stock Exchange after it was put under receivership(Wahome,2011).Ukwala supermarkets chains established in 1995, annual sales in 2007 amounted to US\$120 Million and has got 12 number of outlets in Kenya. Kenyan hyper/supermarkets are the most advanced within East Africa and four major companies (Nakumatt, Tuskys, Uchumi and 


\section{Al Macrothink}

International Journal of Human Resource Studies

ISSN 2162-3058

2015, Vol. 5, No. 2

Ukwala) account for $80 \%$ percent of the total supermarkets market share. In addition, modern supermarkets continue to play an important role in transforming Kenya's food distribution system and buying habits by offering high quality services such as ,pharmacies', bookstores, banking services, delicatessens, and fresh produce section, bakeries, and even in - store restaurants(shop - within - a shop concept.),(Kamau \& Diaby,2008). Based on such characteristics, the study will give preference to supermarkets with more than 10 outlets in Kenya.

\subsubsection{Practice of Health and Safety Measures in Supermarkets in Kenya}

In Kenya supermarkets, safety is the protection of employees from injuries due to work related accidents. These accidents are unplanned and uncontrolled events, which can result in damage to both human and organizational property, so there is need for the organizations to provide employees safety at workplace. This relates to the second level of hierarchy of needs (Nzuve, 2007).The owner manager is the key person, and his or her opinions and values constitute the approach of the organization to health and safety.

OSHA is fairly straightforward it imposes three major obligations on employees first to provide a safe and health working environment to comply with specific occupational safety and health standards and to keep records of occupational injuries and illness under OSHA, employers must record and report work related accidents and injuries (Balkin ,Cardy \& Mejia,2007).

Most supermarkets in Kenya use the Occupation Safety and Health Act (2007), to achieve world's best practice in carrying out appropriate risk assessments in relation to the safety and health of persons employed, and, on the basis of these results, adopt preventive and protective measures to ensure that under all conditions of their intended use. All chemicals, machinery, equipment tools and process under the control of the occupier are safe and without risk to health and comply with the requirements of safety and health provisions in OSHA (Hall, Taylor \& Torrington, 2005).

\subsection{Statement of Problem}

Most organizations have basic requirements that employers must meet as regards the organization of health and safety activities (Hasle \& Limborg, (2005) .Organizations are normally required to establish a management system, which should include a health and safety committee, election of safety representatives and periodical risk assessment (Hasle \& Limborg (2005). Recent fire outbreaks in Kenya's supermarkets have led to scrutiny on the level of preparedness and conformance to health and safety measures taken by employers for both the employees and the customers(Maze, 2009).

According to Mbakaya, Onyoyo, Lwaki \& Omondi (2000), a baseline survey conducted on management perspectives of the state of workplace health and safety practices in Kenya, results from a 65 participants indicated that most workplace managers were not familiar with the Kenyan legislation. Although most respondents $(70 \%)$ were satisfied 
with their work safety conditions ,only $37 \%$ said their workplaces were annually audited by labour inspectors while $45 \%$ said injuries workers were not treated well by management .Many workplaces $65 \%$ violated the mandatory legal requirements on the establishment of health and safety committees. The Occupational health and safety (OHS), resource person and course content were rated highly by respondents( $96 \%)$. The foregoing results provided the basis of a need analysis for future occupational health and safety (OHS) programs in Kenya.

According to Dessler (2008), while employees have a responsibility to comply with occupational safety and health act (OSHA) standards, they often resist, the employer usually remains liable for any penalties. The refusal of some workers to wear hard hats as mandated by OSHA requirements typifies this problem. Employees have attempted to defend themselves against penalties for such non-compliance by citing worker intransigence and their own fear of wildcat strikes and walkouts. Employee commitment to safety and health programs is a major challenge. Many organizations face the problem of employees ignoring and even being hostile to safety and health measures. The reason is that employees often view safety and health measures as intrusive and inefficient. (Balkin, Cardy \& Mejia (2007).

In Kenya the recent Nakumatt Holdings Limited fire tragedy, revealed that instead of facilitating exit upon sensing danger, Nakumatt's employees, anxious to prevent opportunists from looting the stores merchandise, bolted the doors shut, thereby impending and endangering distressed customers (Maze,2009). Supermarkets have learnt that, given that for any single supermarket, the costs of mass disasters are unbearable and further the inefficient $\mathrm{CCN}$ (City council of Nairobi), it is prudent to insure houses and buildings against fires. (Maze, 2009).

Despite studies being done on the importance of health and safety measures such as Mbakaya, Onyoyo, Lwaki, \& Omondi (2000), and Maze (2009) none has focused on the factors affecting the implementation of health and safety measures in supermarkets in Kenya. This study aims at filling the knowledge gap by investigating the factors affecting the implementation of health and safety measures in Kenya supermarkets due to lack of empirical study on the factors affecting the implementation of health and safety measures in supermarkets in Kenya.

\subsection{Objective of the Study}

\subsubsection{General Objective}

The broad objective of the study was to find out the factor affecting the implementation of health and safety measures in supermarkets in Kenya.

\subsubsection{Specific Objectives}

a) To establish whether leadership influences the implementation of health and safety measures in supermarkets in Kenya 
b) To find out whether employee training influences the implementation of health and safety measures in supermarkets on Kenya.

c) To establish whether employee participation influences the implementation of health and safety measures in supermarkets in Kenya.

\subsection{Research Questions}

1. How does leadership influence the implementation of health and safety measures in supermarkets in Kenya?

2. How does employee training influence the implementation of health and safety measures in supermarkets in Kenya?

3. How does employee participation influence the implementation of health and safety measures in supermarkets in Kenya?

\subsection{Justification}

The results of this study will not only benefit human resources managers in general merchandise industry but also in other sectors, as they will be able to understand the long term benefits of implementing health and safety measures, which will lead to increased efficiency, effectiveness and hence productivity. The government will also benefit since the study will contribute to better under understanding of health and safety measures and serve as a basis for further studies in Occupational Health and Safety Act (OSHA).

\subsection{The Scope of the Study}

The study covered the supermarkets with more than 10 outlets in Kenya, and evaluated the roles of employee training, employee participation and leadership adopted by the supermarkets.

\subsection{Limitations of the Study}

The research was devoted to three factors taken as indicators of the implementation of health and safety procedures in supermarkets in Kenya. These were employee training, employee participation and leadership. Confidentiality of the information may restrict the respondents from answering the questions on the questionnaires. The respondents were provided with a letter of introduction from the university.

\subsection{Definition of Terms}

\subsubsection{Employee Participation}

Participation is the mental and emotional involvement of people in-group situations that encourages them to contribute to group goals and share responsibility for them.Thius definition entails three important ideas, contribution and responsibility (Newstrom, 2007). 


\subsubsection{Leadership}

Leadership is the process of inspiring people to do their best to achieve a desired result .It can also be defined as the ability to persuade others willingly to behave differently (Armstrong, 2009),or Leadership is the process of influencing and supporting others at work enthusiastically towards achieving goals(Newstrom,2007).

\subsubsection{Training}

Training is the use of systematic and planned instructions activities to promote learning. The approach can be summarized in the phrase 'learner based training'. It is one of the several responses an organization can undertake to promote learning.(Armstrong,2009).

\section{Literature Review}

\subsection{Introduction}

This chapter analysis literature related to the subject and entails the theoretical review, conceptual framework, empirical review and the research gaps. The review was to explain the research idea, which concerned the factors affecting the implementation of health and safety measurers in supermarkets in Kenya, which included employee participation, employee training and leadership.

\subsection{Theoretical Review}

\subsubsection{Concept of Health and Safety measures}

According to Balkin, Cardy \& Mejia (2007), in managing workplace safety and health, the most recent data from bureau of statistics indicate that in 2003, more than 4.3 million people were injured on the job and 5559 were killed. Currently, the national average per 100 workers is 2.6 workplace injuries or illnesses that are serious enough to result in loss workdays. The cost of occupational accidents was estimated to total and 49.6 million in 2002. All level of government has passed numerous laws to regulate workplace safety. Many of these laws include detailed regulations dealing with work hazards in specific industries such as coal mining and railroads.

However, two basic sets of workplace safety laws affect most workers the various workers compensation laws at the state level and the occupational safety and health Act (OSHA) of 1970 at the federal level. The objectives, policies and operations of these two sets of laws are very different. OSHA is a federal law designed to make workplace safer by ensuring that the work environment is free from hazards (Price, 2004)

According to Nzuve (2007), Health is an employee's freedom from physical or emotional illness. The provision of any health program will vary according to the location and size of the organisation, the kind of work performed, and whether employees include women as well as their proportion in various age brackets. An ideal health program would include the following features. stated health and medical policy adequate health facilities according to size and nature of the organisation; these may 
include first aid and an emergency dispensary ; A registered nurse and a doctor or part time services of a doctor. Medical consulting services periodic examination of employees exposed to health hazards in and out patient schemes; medical insurance covers for immediate dependants (Reese, 2003)

Safety is the protection of employees from injuries due to work related accidents. These accidents are unplanned and uncontrolled events which can result in damage both human being and property. Since organisations provide the work and the physical plant, office, or establishment, it should be committed to doing everything either reason to protect employees from risks associated with spending their working days in those premises (Aamodt, 2007).

Each, employer must become familiar with and comply with specific occupations standards. (OSHA'S rules deal with specific occupations rather than with industries); and must make certain than employees comply as well and to keep records of occupational injuries and illness (Cullen, 2002).Under OSHA, employers must keep records of any occupational injury and illness resulting in death, lost work time, or medical treatment and retain these injuries and illness must be recorded on OSHA forms and posted annually on an employee bulletin board for all to see. These records must also be made available to OSHA compliance officers, and annual summarises must be prepared (O’Brien, 2001).

According to Dessler (2008), OSHA primary responsibility for enforcing OSHA. It develops occupational standards, grants variances to employers, and conducts workplace inspections and issues citations and penalties. Example of development of standards is OSHA'S proposed National ergonomics standards. The national institute for occupational safety and health reported in 1997 that musculoskeletal disorders related to the neck shoulders, elbow, hand, whist and back generated at least and 13 million a year in workers, compensation costs. Further, the Bureau of labour statistics reported that the incidence rate for cumulative trauma disorders per 10000 fulltime workers jumped from 6.3 in 1985, to 335 in 1996.based on these and other findings, OSHA began looking seriously at developing ergonomics standards (Decenzo \& Robbins, 2007).

For all areas of human activity, a balance has to be made between benefits and costs of risk taking. In the case of OSH, this complex balance is influenced by many factors such as rapid scientific and technological progress, a very diverse and continuously changing world of work, and economics. The fact that the application of the OSH principles implies the mobilization of all social and scientific disciplines is a clear measure of the complexity of this field. The concepts of hazard and risk and their relationship can easily lead to confusion (Walters, 2003).

According to International Labour Organization (2011, April 28), a hazard is the intrinsic property or potential of a product, process or situation to cause harm, adverse health effects on someone or damage to something. It can come from a chemical (intrinsic properties), working on a ladder (situation), electricity, a compressed gas 
cylinder (potential energy), a fire source or more simply a slippery floor. Risk is the likelihood or probability that a person will be harmed or experience adverse health effects if exposed to a hazard or that property will be damaged or lost. The relationship between hazard and risk is exposure, whether immediate or long term, and is illustrated by a simple equation:

$$
\text { Hazard } \mathrm{x} \text { Exposure }=\text { Risk }
$$

As described before, the essential purpose of OSH is the management of occupational risks.

In order to do that, hazard and risk assessments have to be carried out to identify what could cause harm to workers as well as property so that appropriate preventive and protective measures can be developed and implemented. The five step risk assessment method shown below was developed by the Health and Safety Executive in the United Kingdom as a simple approach to manage risks, particularly in small scale enterprises (SMEs) and has been endorsed globally (Institution of Occupational Safety and Health,2009):

Table 2.1 Risk Assessment and Management

\begin{tabular}{|l|l|}
\hline Step 1 & Identify the hazard \\
\hline Step 2 & Decide who might be harmed and how \\
\hline Step 3 & Evaluate the risks and decide on the precautions \\
\hline Step 4 & Record your findings and implement them \\
\hline Step 5 & Review your assessment and update if necessary \\
\hline
\end{tabular}

Source: International Labour Organization (ILO), 2011, April 28.

According to O'Brien (2001), risk assessment procedure can be easily tailored to the size and activity of the enterprise, as well as to the available resources and skills. A major hazard installation, such as a petrochemical plant will require highly complex risk assessment evaluations and mobilize a high level of resources and skills. Many countries develop their own risk assessment guidelines which are often used for regulatory purposes or to develop internationally agreed standards. Two risk assessment processes which are essential for the management of occupational risks are the determination of occupational exposure limits (OEL) and the establishment of lists of occupational diseases (Hammer \& Price, 2001). 
Most of the industrialized countries establish and maintain OEL lists. These limits cover chemical, physical (heat, noise, ionizing and non ionizing radiation, cold), and biological hazards. One list that is outstanding in terms of coverage and strong scientific peer-review process, and therefore used as a reference by other countries, is the List of Threshold Limit Values (TLVs) of the American Conference of Governmental Industrial Hygienists (ACGIH) (International Labour Office,2008).

According to International Labour Organization (2011,April,28), the incorporation of occupational diseases in national lists is also based on hazard and risk assessment procedures for the identification and recognition of occupational diseases for compensation purposes. These range from illnesses such as respiratory and skin diseases, musculoskeletal disorders and occupational cancer to mental and behavioral disorders. The ILO List of occupational diseases (revised in 2010), assists countries in the design of their own national lists, in prevention, recording, notification and, when applicable, compensation of diseases caused by workplace exposure (Institution of Occupational Safety and Health, 2009).

The notion of management systems is used often in the decision making processes in business and unknowingly also in daily life, whether it is in the purchase of equipment, the extension of business or more simply the selection of new furniture. The application of Occupational Safety and Health Management Systems (OSHMS) is based on relevant OSH criteria, standards and performance (Walters, 2003). It aims at providing a method to assess and improve performance in the prevention of workplace incidents and accidents via the effective management of hazards and risks in the workplace. It is a logical, stepwise method to decide what needs to be done, how best to do it, monitor progress toward the established goals, evaluate how well it is done and identify areas for improvement. It is and must be capable of being adapted to changes in the business of the organization and to legislative requirements (Kogi, 2002).

Fig: 2.1 Plan - Do - Check -Act Deming Cycle

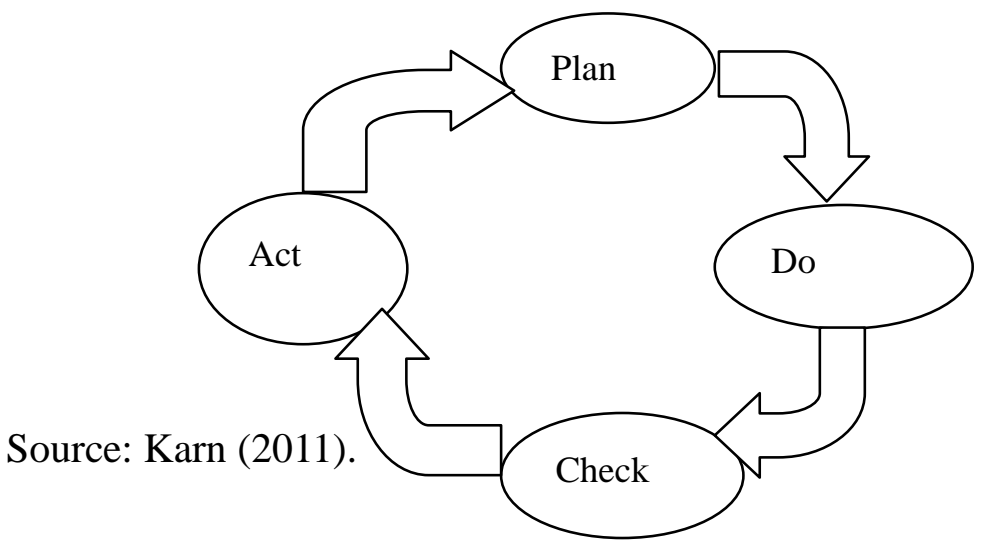

This concept of a process is based on the principle of the "Plan-Do-Check-Act" Deming Cycle (PDCA), designed in the 1950s to monitor business performance on a continual basis. When applied to OSH, "Plan" involves the setting of an OSH policy, planning 
including the allocation of resources, provision of skills and organization of the system, hazard identification and risk assessment. The "Do" step refers to actual implementation and operation of the OSH programme. The "Check" step is devoted to measuring both the active and reactive performance of the programme. Finally the "Act" step closes the cycle with a review of the system in the context of continual improvement and the priming of the system for the next cycle (Easter, Hegney \& Taylor, 2004).

An OSHMS is a logical toolbox that is flexible and can be tailored to the size and activity of the organization and be focused on general or specific hazards and risks associated with such activity. Its complexity can range from the simple needs of a small enterprise running a single product process where hazards and risks are easy to identify, to multiple hazard industries such as mining, nuclear power, chemical manufacturing, or construction (Hammer \& Price, 2001). The OSHMS approach ensures that: the implementation of preventive and protective measures is carried out in an efficient and coherent manner; pertinent policies are established; commitments are made; all the workplace elements to assess hazards and risks are considered, and management and workers are involved in the process at their level of responsibility (Kogi, 2002).

\subsubsection{Understanding Health and Safety Measures}

According to Balkin, Cardy and Mejia (2007), effectively managing workplace safety and health requires far more than reducing the number of job related accidents and injuries. In practice, legal and ethical issues, many of which involve a careful balancing of individual rights (particularly the right of privacy).with the needs of the organisation, because these issues often give rise to legal questions.HR professionals are frequently called upon to develop and implement policies to deal with them. Among the weightiest issues facing employers today are dealing with AIDS in the workplace, workplace violence, smoking in workplace, cumulative trauma disorders, hearing impairment, fetal protection, hazardous chemicals, and genetic testing.

According to Armstrong (2009), Health and Safety training is a key part of the preventive programme. It should also take place following a transfer to new job or a change in working methods. Safety training spells out the rules and provide information on the potential hazards and how to avoid them. It is important to recognise that in addition to these direct challenges, there is also the challenge of employees' commitment to safety and health programs. Many organisations face the problem of employees ignoring and even being hostile to safety and health measures. The reason, employees often view safety and health measures as intrusive and inefficient (Khanka, 2007).

According to Dessler (2008), OSHA operates under the "general "standard clause that each employer ......, shall furnish to each of his or her employees employment and a place of employment which are free from recognised hazards that are causing or are likely to cause death or serious physical harm to his or her employees. To carry out the basic mission, OSHA is responsible for promulgating legally enforceable standards. These are contained in five volumes covering general industry standards, maritime standards 
construction standards other regulations and procedures, a field operations manual (Hammer \& Price, 2001).

Under OSHA, employers with eleven or more employees must maintain records of and report certain occupational injuries and occupational illness is any abnormal condition or disorder caused by exposure to environmental factors associated with employment. These include acute and chronic illness caused by inhalation, absorption. Ingestion or direct contact with toxic substances or harmful agents (O'Brien (2001). The elements of Workplace Safety and Health include Safety, which involves protecting employees from injuries due to work-related accidents. Occupational Safety and Health (OSH) is a discipline dealing with the prevention of work related injuries and diseases as well as the protection and promotion of the health of workers. It aims at the improvement of working conditions and environment (Cullen, 2002).

Occupational Health entails the promotion and maintenance of the highest degree of physical and mental health and social well-being of workers in all occupations. In this context, the anticipation, recognition, evaluation and control of hazards arising in or from the workplace that could impair the health and well-being of workers are the fundamental principles of the process governing occupational risk assessment and management (International Labour Organization (ILO), 2011 April 28).

According to Walters (2003), the possible impact on the surrounding communities and the general environment should also be taken into account. The basic learning process about hazard and risk reduction is at the root of the more sophisticated principles governing today's OSH. In present times, the need to master a galloping industrialization and its demand for highly and inherently dangerous energy sources, such as the use of nuclear energy, transport systems and increasingly complex technologies has led to the development of much more sophisticated risk assessment and management methods ( World Day for Safety and Health at Work, 2011 April 28).

\subsubsection{Approaches to Health and Safety in Organizations}

Health which refers to the employees' freedom from physical or emotional illness and Safety programs may be designed to accomplish their purposes in two primary ways. The first approach is to create a psychological environment and attitudes that promote safety. A strong company policy emphasizing safety and health is crucial. The second approach to safety program design is to develop and maintain a safe physical working environment (Reese, 2003).

According to Armstrong (2010), on safety programmes, it has become clear that optimal health can generally be achieved through environmental safety, organizational changes, and different lifestyles. Developing Safety Programs organizational safety programs require planning for prevention of workplace accidents. Plans may be relatively simple or more complex and highly sophisticated in order to fit the organization's size. Top management's support is essential if safety programs are to be effective. Tremendous 
economic losses can result from accidents. The main goal of safety and health professionals is to prevent job-related injuries and illnesses (Gerhart, Hollenbeck, Noe \& Wright (2008).

According to Armstrong (2009), Health and safety policies and programmes are concerned with protecting employees and people affected by what the company produces and does against the hazards arising from their employment or their links with the company .Safety programmes deal with the prevention of accidents and with minimizing the resulting loss and damage to people and property. They relate more to systems of work than the working environment, but both health and safety programmes deal with the prevention of ill health arising from working conditions. They consist of two elements, that is occupational medicine, which is a specialized branch of prevention of health hazards at work and dealing with any ill health or stress which as occurred in spite of preventive actions, and occupational hygiene, which is the province of the chemist and the engineer or ergonomist engaged in the measurement and control of environmental hazards.

According to Muchoki (2011), Matters relating to occupational safety and health never used to be as prominent in the minds of most Kenyans. Not anymore. Things have since changed, tremendously. Many Kenyan companies and organizations are now keen to know more about issues appertaining to occupational safety and health. "We have had a positive impact in terms of awareness creation".

Today, people seem to be aware that there is something called health and safety and it's important for them, and they are even coming to us; looking for information and support in terms of developing systems that can work to help them do better," notes the Director of Occupational Safety and Health (OSH) Services Director Mr. Pius Makhonge, and the Directorate has always been at hand to guide Kenyans in marking the World Day for Safety and Health at work on April 28 every year, in commemoration and solidarity with workers who have lost their lives or been injured in the course of their work. The day is usually preceded by a week-long campaign packed with activities meant to sensitize workers and employees on issues relating to occupational health and safety (Muchoki, 2011).

OSHMS cannot function properly without the existence of effective social dialogue, whether in the context of joint safety and health committees, or other mechanisms such as collective bargaining arrangements. Workers and their representatives should be given the opportunity, through direct involvement and consultation, to fully participate in the management of $\mathrm{OSH}$ in the organization. A system is successful only when all the stakeholders are given defined responsibilities in running it. A major principle of OSHMS is the establishment of a line management responsibility, including the meaningful involvement of all employees at all levels in the organization, and with defined OSH responsibilities (International Labour Office, 2008). 
It has been demonstrated again and again that the implementation of $\mathrm{OSH}$, and even more of OSHMS, can be successful only when all stakeholders participate fully in this implementation through dialogue and cooperation. In the case of OSHMS, a system run solely by managers without input from workers at lower levels in the hierarchy is bound to lose its focus and fail (Dohery \&Tyson, 2000). A number of studies suggest an association between lower lost-time injury rates and the presence of joint OSH committees and trade union involvement in the organization. Other studies indicate that participatory workplace arrangements lead to OSHMS practices resulting in improved OSH performance, and this is even more so in unionized workplaces (Walters, 2003).

\subsubsection{Strengths and Limitations of Occupational Safety and Health Management Systems (OSHMS).}

It is now recognized that the management systems' approach brings a number of important advantages to the implementation of OSH, some of which have been already identified further above. A systems' approach also adjust the overall safety and health programme over time so that decisions on hazard's control and risk reduction improve progressively. (International Labour Organization (ILO), 2011 April 28,).

Other key advantages are: the possibility of integrating OSH requirements into business systems and aligning OSH objectives with business objectives, thus resulting in a better taking into account of implementation's costs related to control equipments and processes, skills, training and information; harmonizing OSH requirements with other related requirements, particularly those pertaining to quality and environment, providing a logical framework upon which to establish and run an OSH programme that tracks all the elements requiring action and monitoring; streamlining and improving communication mechanisms, policies, procedures, programmes, and objectives according to a set of rules applied universally; Applicability to differences in cultural and national regulatory systems; establishing an environment conducive to the building of a preventative safety and health culture; strengthening social dialogue; distributing OSH responsibilities along the line management, involving all: managers, employees and workers have defined responsibilities for an effective implementation of the system; adapting to the size and activity of the organization, and to the types of hazards encountered establishing a continuous improvement framework; and, providing an auditable baseline for performance evaluation (Kogi, 2002).

According to International Labour Organization (ILO), (2011 April 28), while the potential of OSHMS for improving safety and health is undeniable, there are many Pitfalls which, if not avoided, can very rapidly lead the exercise toward failure. The usefulness of OSHMS has been questioned in several studies on the subject, and a number of potentially serious problems have been underlined, such as: the production of documents and records needs to be controlled carefully to avoid defeating the purpose of the system by drowning it in excessive paperwork. The focus on the human factor can be easily lost if the emphasis is more on the paperwork requirements of a formal OSHMS 
than people (Reese, 2003).

Imbalances between management processes (quality, OSH, environment) must be avoided to prevent dilution of requirements and inequalities in focus. The lack of careful planning and full communication prior to the introduction of an OSHMS programme can raise suspicions about and resistance to the change. OSHMS usually puts greater emphasis on safety rather than health and with the risk of missing the onset of occupational diseases. Occupational health surveillance of workers must be incorporated in the system as an important and effective tool for monitoring the health of workers over the long term (Walters, 2003). Occupational health services, such as defined in the ILO Occupational Health Services Convention, 1985 (No. 161) and its accompanying Recommendation (No. 171) should be an integral part of OSHMS (International Labour Organization (ILO), 2011 April 28,).

\subsection{Conceptual Framework}

Conceptual framework identifies the concepts under the study and their relationship (Mugenda \&Mugenda, 2003).This study was based on a framework that was aimed at explaining the relationship between the dependent and independent variable which was the implementation of health and safety measures and the dependent variables which were leadership ,employee participation and employee training.

The study adopted a conceptual framework shown in the figure 2.2.

\section{Independent Variables} Variable

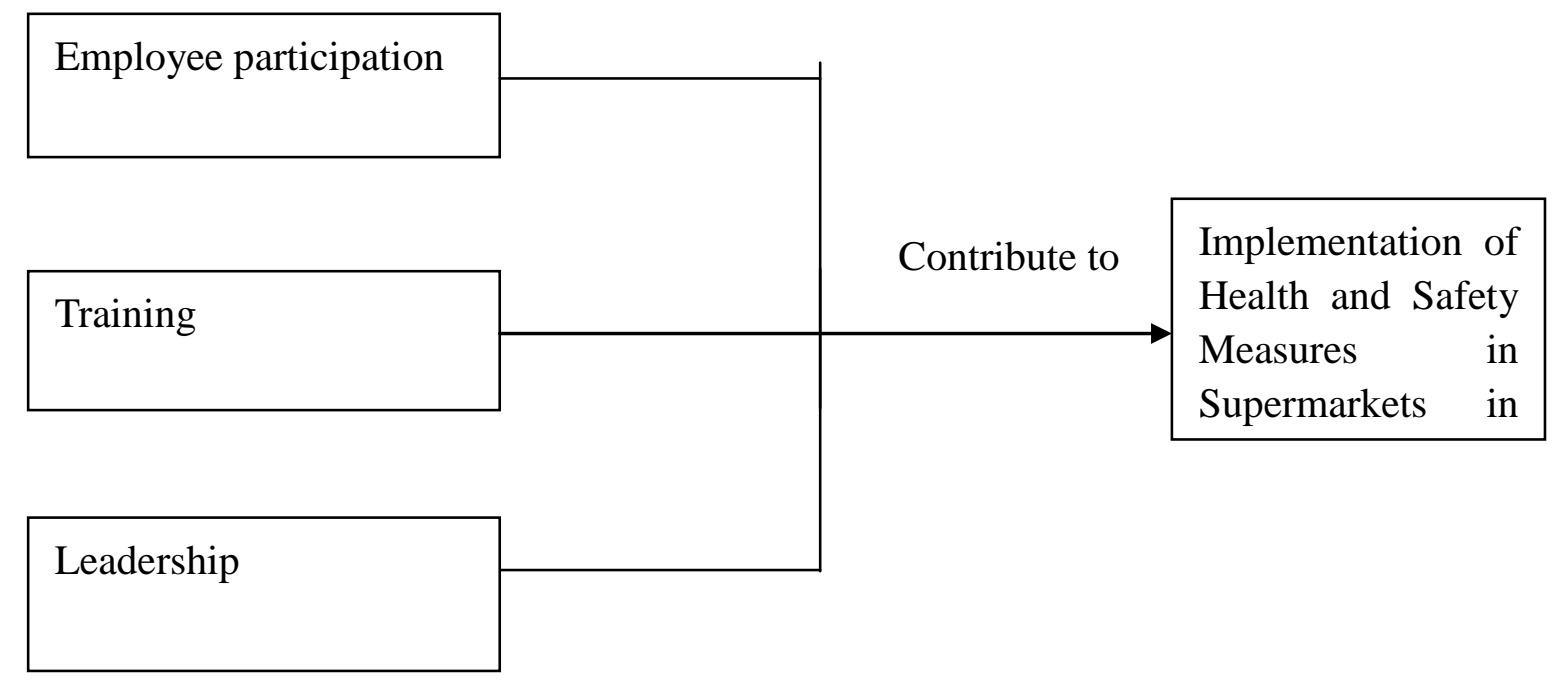

\section{Dependent} Health and Safety Measures in Supermarkets in 


\subsubsection{Training}

According to Decenzo \& Robbins (2010), OSHA'S extensive website provides an enormous amount of practical, easy to read and understand information for employees and employers. Regulations are clearly defined and compliance and inspection procedures are explained in simple terms. Education and training are a major emphasizes of the OSHA website and include handbooks for small business, email newsletters training program information and interactive online training called "e tools" that covers dozens of occupational safety and health tops.

According to Armstrong (2010), managers have a vital role in helping their people to learn and develop. Most learning takes place on the job but it will be more effective if managers provide the coaching, guidance and support peoples' needs. To do this they need to know about induction training how to ensure continuous learning, and personal development planning processes. In induction training you are involved in helping people to learn every time you welcome new employees, plan how they are going to acquire the knowhow required, preferably as recorded in a learning specification, provides for them to carry out and see that the plan is implemented.

According to Nzuve (2007), people should never be allowed to operate machines, appliances and equipments until they know how to operate them safely. Safety training is designed to prevent physical harm to both people and organizations property. This would include physical measures such as how to maintain plant, machines, appliances, equipment and buildings. Training and development may also include career development activities and employee counseling to help people make better choices about their careers and to achieve their desired goals (Cascio, 2006).

\section{Table 2.2: Health and Safety Training Procedure}

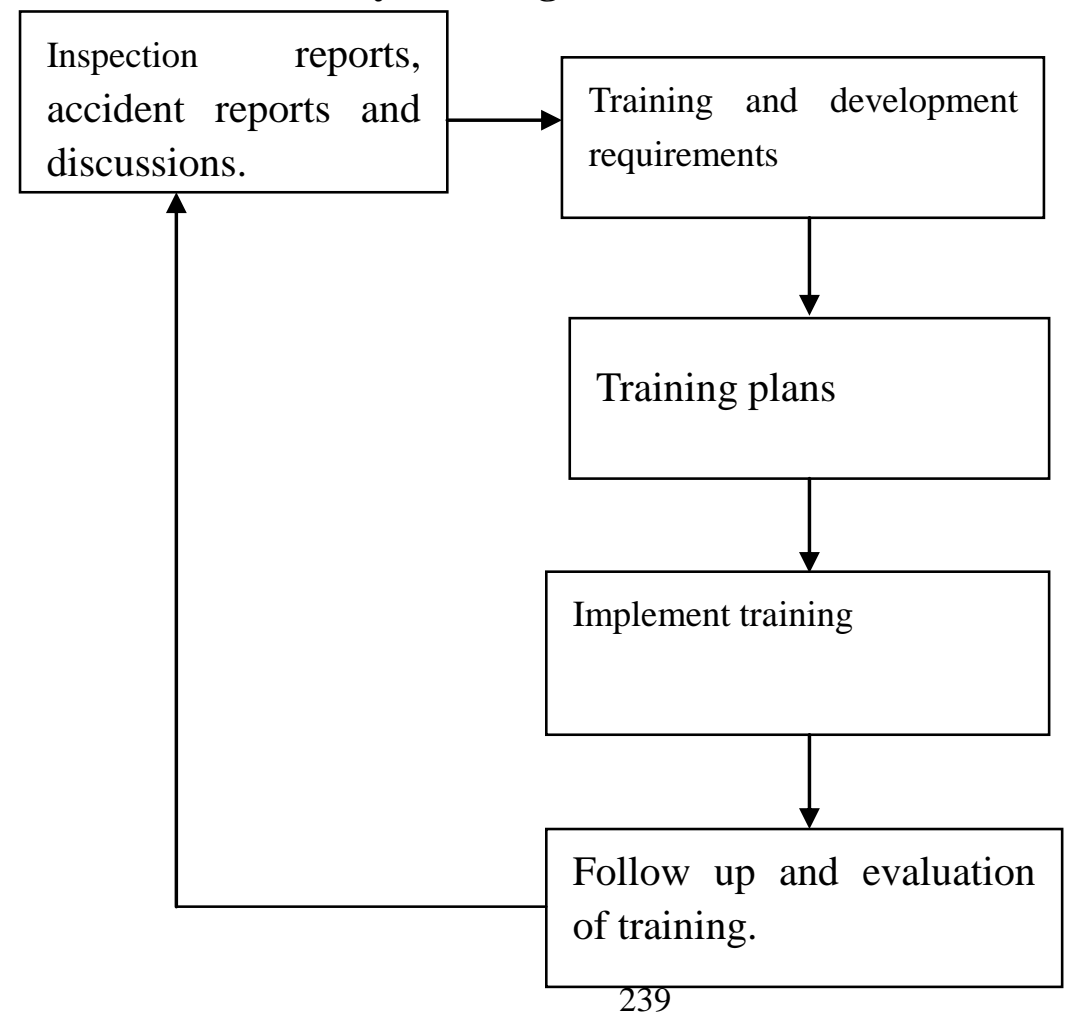


Source: (Kaplan Financial Limited, 2009).

According to Hall, Taylor \& Torrington (2005), safety training has three major purposes; employees should be told about and understand the nature of the hazards at the place of work; employees need to be aware of the safety rules and procedures; and the need to be persuaded to comply to them. Safety training need to be carried out in three setting; at the induction, on the job and in refresher courses. A variety of different training techniques can be employed, including lectures, discussions, films, role playing and slides. These methods are sometimes supplemented by poster or other safety awareness campaigns and communications, and disciplinary action for breaches of the safety rules (Easter, Hegney \& Taylor, 2004).

According to Muruka (2004), Learners should access intensive induction and continuous tailor-made training programmes, designed by professional curriculum developers ,to new and potential workers in the labour market. It is proposed that the costs for employees and expert training be met from increased budgetary allocations, training levy, World Health Organization (WHO) collaborating centres and International Labour Organization (ILO) centres. Adequate resources should be allocated for staff training and development at the Occupational Health and Safety (OHS) as the most desirable proactive measures to prevent Occupational injuries and associated costs. The costs should be met from all stakeholders (Mearn \& Hope, 2005).

\subsubsection{Leadership}

According to Armstrong (2009), leadership is the process of inspiring people to do their best to achieve a desired result. It can also be defined as the ability to persuade others willingly to behave differently. The function of team leaders is to achieve the task set for them with the help of the group. According to Nzuve (2007), to a large extent the attitude of the rank and file towards safety is a reflection of the attitude of their supervisors. Line managers should set examples not merely by telling but by demonstrating the seriousness of safety and health measures.

Accidents are partly the fault of individuals, partly of technology and partly of the result of such factors as group attitudes and improper supervision. In light of this, safety must be considered as the responsibility of the whole organization (Cullen, 2002). Any attempt to departmentalize it one common technique for reinforcing safe practices is implementing a safety incentive program to reward workers for their support and commitment to safety goals .Initially programs are set up to focus on improving short term monthly or quarterly goals or to encourage safety suggestions (Gerhart, Hollenbeck, Noe \&Wright, 2008), may inevitably lead to confusion and inefficiency.

Safety program could succeed through formulation of safety policy that aims at making the place of work safe in all aspects. Such a policy should be in writing and issued as an official statement by top management, safety education for all levels accident analysis and enforcement of safety rules. Dohery \& Tyson (2000) argue persuasively that 
managers are not innocent by standers with regard to employee health and wellbeing: their actions such as choice of production processes and substances, work speed -up extra work hours and performance based pay have adverse effects on employees work life balance, and their physical and mental wellbeing.

A major challenge to managers is clearly to provide a safe and Health work environment for employees. Economic and moral reasons dictate such a policy, but there is also a persuasive portfolio of legislation, regulations, codes of practice and guidance notes dealing with the occupational Health and Safety, and, as with other employment law, the HR practitioner has taken on the role of advising managers on the content and legal obligations of this(Bratton \& Gold,2009).

Table 2.3 Strategies to improve workplace Health and Wellness.

\begin{tabular}{|l|l|l|}
\hline 1 & Design & Safe and Healthy systems of the work. \\
\hline 2 & Exhibit & Strong management commitment to programmes \\
\hline 3 & Inspect & The workplace for health and safety hazards. \\
\hline 5 & Promote & A workplace wellness strategy \\
\hline 6 & Develop & A safety training programme \\
\hline 7 & Set up & A health ,wellness and safety committee \\
\hline 8 & Monitor & Health, wellness and safety policies and programmes \\
\hline 9 & Integrate & $\begin{array}{l}\text { To form a comprehensive wellness system that supports } \\
\text { strategy }\end{array}$ \\
\hline 10 & Draw up & An action plan and checklist. \\
\hline
\end{tabular}

\section{Source: Bratton \& Gold (2009).}

Health and Safety policies work better if senior managers set examples and show that they are committed to their upkeep (O'Brien, 2001). The policy will not be enforced if managers set a bad example. To avoid this they should involve staff in the health and safety process, through consultation with unions or workplace committees, ensure that employees are aware of the document and the specific contents hat applies to them for 
example newsletters and memoranda, visibly react to breaches of the policy (Kaplan Financial Times, 2009).

According to Hall Taylor \& Torrington (2005), the Health and Safety Regulations 1996, require employers to consult collectively with the employees about Health and Safety matters irrespective of whether a trade union is recognized. Consultation is defined as discussing issues with employee representatives, listening to their views and taking into account when decisions are being made which have Health and Safety implications (Mearn \&Hope, 2005). Where trade unions are recognized require that their representatives are consulted. Management's first duty is to formulate a safety policy. Its second duty is to implement and sustain this policy through a loss control program such a program has four components; a safety budget, safety records, Managements personal concern and management's good example (Cascio, 2006).

\subsubsection{Employee Participation.}

Participative managers consult with their employees, bringing them in on problems and decisions so that they work together as a team. Participation is the mental and emotional involvement of people in-group situations that encourages them to contribute to group goals and share responsibility for them. This definition entails three important ideas; involvement, contribution and responsibility (Newstrom, 2007).

According to Dessler (2008), there are two good reasons to get involved in designing the safety Program. First, the employees are often management's best source of ideas about what the potential problems are and how to solve them. Second, employee involvement tends to encourage employees to accept the safety program. According to Balkin, cardy \&Mejia (2007) effective safety programs often include the information of a safety committee and participation by all departments within the company or organization. Employees participate in safety decisions and management carefully considers employees suggestions for improving safety.Companies with comprehensive safety programs are likely to be rewarded with fewer accidents, fewer worker's compensation claims and lawsuits, and lower accidents related costs. Keep in that OSHA considers employee involvement a key feature of a successful safety program Organizations often involve employees by establishing a safety committee (HSC/DETR, 2000).

Top managers can generate commitment to safety and health programmes by explaining to supervisors and others the rationale for the relevant safety and health practices. For example, it is important that everyone understand the costs of accidents to the organisation. Further costs (such as fine) for violating safety and health standards should be clearly explained to employees at all levels (Casio, 2006). Once people understand the linkage between safety measures and the business bottom line, résistance to safety programmes should largely disappear of course, removing human resistance to any kind of programme can be difficult and delicate process that requires time and commitment (Dyck, 2002). 
Full workers' participation is strongly promoted in all ILO OSH standards, and particularly in the ILO Convention on Occupational Safety and Health, 1981 (No. 155) and its accompanying, recommendation (No. 164), as well as in the ILO Guidelines on OSHMS. For joint OSH committees and similar arrangements to be effective, it is important that adequate information and training is provided, that effective social dialogue and communication mechanisms are established, and that workers and their representatives are involved in the implementation of $\mathrm{OSH}$ measures (International Labour Organisation, 2011, April, 28).

Although participation in OSHMS is usually understood to refer to employers and workers in the organization, participation in the sense of information exchange and communication should also concern out-sourced and external stakeholders in the implementation of measures. These may include regulators, subcontractors, neighboring communities and organizations, clients and enterprises in the supply chain, insurers, shareholders and consumers, as well as international standard setting bodies (Kogi, 2002).

OSH related training at all levels, from managers to workers, is a major element in implementing any OSH programme. This training has to be carried out on a continual basis to ensure knowledge of the system and for instructions to stay up to date with changes in the organization. In this context communication channels between the different levels of the organization must be effective and go both ways, meaning that OSH related information and concerns conveyed by shop floor workers should be given due consideration and allowed to reach higher management. This is an example of what is meant by the need for the system to focus on people (Institution of Occupational Safety and Health, 2009).

OSHMS should not be regarded as the panacea or solution for increasing the performance of the organization in ensuring and sustaining a safe and healthy working environment. As any method, OSHMS has both advantages and weaknesses, and its effectiveness is very much dependant on how it is understood and applied (Cullen, 2002). While most organizations will probably benefit from a full OSHMS, some might consider using a scaled down, less formal approach to the management of OSH. The decision of moving to OSHMS may be sometimes difficult to justify as the distinction between a programme and a system is a potentially weak one (Kogi, 2002).

Programmatic approaches, such as that promoted in the ILO OSH Convention, 1981 (No. 155) do in fact contain systems' features and similarly, systems' approaches do in fact contain programmatic features. This is also the case in a large number of national $\mathrm{OSH}$ legislation. However, systems management brings to OSH the possibility of establishing mechanism for not only continual assessment and improvement of OSH performance, but also for the building of a preventative safety and health culture, as defined in the ILO Global Strategy on OSH (2003) and the ILO Convention on a Promotional Framework for Occupational Safety and Health, 2006 (No. 187).The 
performance of an OSHMS can only be as good as the performance of the overall management of the organization. Like all methods, it has both strengths and weaknesses which should be known (International Labour Organization, 2011, April, 28).

It is therefore important to be aware of the pitfalls that may derail the operation of an OSHMS, but also know what elements must be in place to ensure a good performance and benefit from the important advantages of OSHMS for safety and health. It must be kept in mind that these strengths and weaknesses apply mostly to medium and large organizations which have the necessary technical and financial resources for a full implementation of OSHMS. It is very important to remember that OSHMS is a management method and not an OSH programme in itself (Kogi, 2002). Therefore, a management systems' approach is only as good as the OSH framework or programme in place in the organization. OSHMS programmes must function within the national OSH legislation framework and the organization must ensure that the system include a review of regulatory requirements and is updated accordingly to integrate them (Walters, 2003).

\subsection{Critique of Existing Literature Review}

According to Hull Reinforcement theory (Hull,1951), as experience is gained in satisfying needs people perceive that certain actions help to achieve goals while others are unsuccessful. The successful actions are repeated when a similar need arises. Employees have a responsibility to comply with occupational safety and health Act standards, but resist; the employer usually remains liable for any penalties. The refusal of some workers to wear dust coats and gloves as mandated by OSHA requirements typifies this problem; yet both employer and employees have the responsibilities and rights under the occupational safety and Health Act. He does not clearly indicate how these can be done .So employers can serve this purpose through positive reinforcement and training for gaining employee compliance.

\subsection{Summary of Findings}

Successful organizations are discovering Occupational Safety and Health as a important business tool; one that deals with the prevention of accidents and with minimizing the result loss and damage to people and property .success with Occupational Safety and Health does not happen automatically, it requires commitment. The Human Resource Department is responsible for implementing and maintaining OSHA standards must ensure that the top management understands the potential of effective OSHA standards and is committed to its success. With that commitment in place, written health and safety policies are required to demonstrate that top management is concerned about the protection of the organization's employees from hazards at work and to indicate how this protection will be provided. The policy statement should consist of three part; the general policy statement, the description of the organization for health and safety and details of arrangements for implementing the policy (Armstrong, 2009). 


\subsection{Research Gaps}

Many studies like a survey on management perspectives of the state of workplace health and safety practices in Kenya (Mbakaya, Onyoyo, Lwaki \& Omondi ,2000) and a review of literature on preventive occupational health and safety in small enterprises (Hasle \& Limborg ,2005) show that organizations have problems with fulfilling legal requirements for the control of occupational health and safety. The fact of limited resource and cost of implementing control measures is relatively high in organizations (Hasle \&Limborg, 2005).Human resources managers are thus left with dilemma of how to persuade their chief executive officer (C.E.O) and fellow managers of the effectiveness of implementing health and safety measures.

All these studies indicate that no major research has been done to explain the factors affecting the implementation of health and safety measure in supermarkets in Kenya. This has in result influenced existence of a knowledge gap on the how employee training, leadership and employee participation influence implementation of health and safety measures. This research study thus gave focus on the missing gaps in order to give appropriate recommendations on how human resource managers should implement health and safety measures in organizations.

\section{Research Design And Methodology}

\subsection{Introduction}

The chapter outlines the methodology the researcher used during the research. It discussed the target population and sample size, explained the data collection instruments and procedures and subsequently, gave a summary of methods used in data analysis and presentation.

\subsection{Research Design}

The research design used in the study was descriptive in nature, as it used both qualitative and quantitative techniques to describe the factors affecting the implementation of health and safety measures in supermarkets in Kenya. According to Gathuthi, Kosgei \& Ng'ang'a (2009), in descriptive study designs, the researcher describes or presents a picture of a phenomenon or phenomena under investigation. The possible approaches include participants' observation where the researcher interacts naturally with the respondents in a natural setting making and recording his or her observations without undue influence on the respondents.

Descriptive research design involves measuring a variable or set of variables as they exist naturally. It is not concerned with the relationship between variables but rather with description of individual variables. According to Sekaran (2006), in a descriptive study in order to ascertain and be able to describe the characteristics of the variables of interest in a situation, descriptive studies are also undertaken to understand the characteristics of organizations that follow certain common practices. According to Chapman \& McNeil 
(2005), descriptive research aims only to describe, in detail a situation or set of circumstances. It aims to answer questions like 'how many? or 'who?' and' what is happening?'

\subsection{Target Population}

The target population was the general retail merchandise market in Kenya. The study population was the supermarkets in Kenya. The supermarkets were of interest because they constituted a big percentage as employers making them suitable for the study. The target population was 18 human resource department staff.

\subsection{Sample Size and Sampling Technique}

According to Panneerselvan (2004), 'census' is the process of obtaining responses from /about each of the members of the population. Under census method, one has to collect data from each individual of the population. If the size of the population is manageable, one can resort to census method. A census method was used to make it possible to survey the whole population of Supermarkets with more than 10 outlets in Kenya. A complete enumeration of all the items in the "population" is known as census inquiry. It can be presumed that in such an inquiry when all the items are covered, no element of chance is left and highest accuracy is obtained. However, in practice this may not be true. Even the slightest element of bias in such as inquiry will get larger and larger as the number of observations increases (Kumar, 2008). Respondents were drawn from human resource department. The sample size was equal to the target population.

\subsection{Data Collection Instruments.}

The study used primary data, which were to be collected through self-administered questionnaires. According to Kothari (2004), a questionnaire consists of a number of questions printed or typed in a definite order on a form or set of forms. Quite often, a questionnaire is considered as the heart of a survey operation. The questionnaires adopted in this study will have both open ended and closed ended questions, and the likert question scale will be utilized. According to Mugenda \& Mugenda (2003), this procedure requires a higher level of inference on the part of the observer since it involves observation and evaluation.

According to Gathuthi, Kosgei \& Ng'ang'a (2009), in open-ended questions, the researcher receives the answer open to what a respondent wishes to give. The advantages include, free expressions, responses not biased and used to start an in depth interview, it also sets interview at ease. Open-ended questions allow respondents to answer them in any way they choose. A closed question in contrast would ask the respondents to make choices among a set of alternatives given by the researcher.Closed ended questions help the respondents to make quick decisions to choose among the several alternative before them (Sekaran,2006). 


\subsection{Pilot Testing.}

According to Cooper \& Schindler (2003), pilot testing is intended to reveal errors in the design and improper control of extraneous or environment conditions. Pre testing the instruments permits refinement before the final test. The data collection instruments for this study were tested for reliability and validity. Content validity is content validation is a matter of determining if the content that the instrument contains is adequate (Gathuthi, Kosgei \& Ng'ang'a, 2009). It checks the format of the instrument. Content validity of a measuring instrument is the extent to which it provides adequate coverage of the investigative questions guiding the study (Cooper $\&$ Schindler, 2003).

The study involved selecting 6 respondents from the supermarkets with less than 10 outlets in Kenya, 3 of which were issued with questionnaires. Cronbach's alpha is a reliability coefficient requires only a single test administration to provide a unique estimate of the reliability for a given test (Gliem \& Gliem, 2003). Reliability has to do with the accuracy and precision of a measurement procedure. Reliability is a necessary contributor to validity but is not a sufficient condition for validity. Reliability is concerned with estimates of the degree to which a measurement if free of random or unsuitable error (Copper \&Schindler 2003). Cronbach's alpha reliability coefficient normally ranges between 0 and 1.The closer Cronbach's alpha coefficient is to 1.0 the greater the internal consistency of the items in the scale (Gliem \& Gliem, 2003).

\subsection{Data Analysis and Presentation}

According to Mugenda \&Mugenda (2003), data analysis is the process of bringing order, structure and meaning to the mass of information collected. Data analysis methods employed involved quantitative and qualitative procedures. Quantitative data was analyzed using descriptive statistical methods. This study employed measures of central tendency, which included the mean, mode and the median.

Quantitative data analysis was aided by SPSS (Statistical Package for Social Sciences) Version 17 to produce mean score, percentages and frequencies. Percentages are the most widely used and understood standards proportions. (Onwong'a, Mamati, Kangu \& Osongo,2010). SPSS Version 17 has got descriptive statistics features that assist in variable response comparison and gives a clear indication of response frequencies (Mugenda, 2008) or SPSS Statistics 17.0 is a comprehensive system for analyzing data. SPSS Statistics can take data from almost any type of file and use them to generate tabulated reports, statistical analyses (Marija, 2008).

In qualitative data analysis, data was analyzed by coding and organizing it into themes and concepts in line with the objectives of the study and content analysis technique. Content analysis is a systematic qualitative description of the composition of the objects or materials of the study (Mugenda \&Mugenda, 2003). The study was presented in statistical tables and pie charts and gave a graphical representation on the factor affecting the implementation of Health and Safety measures in supermarkets in Kenya. 
Pearson's product correlation was used to analyze inferential statistics. Pearson product correlation is used when both variables that the researcher wishes to study are measured at ratio or interval scales and are continuous like age, income and years of education. (Mugenda \& Mugenda, 2003). The correlation coefficient measures the strength of a linear relationship between two variables. The dependent and independent variables move uniformly together meaning there is a perfect direct linear relationship.

The correlation coefficient is always between -1 and +1 . The closer the correlation is to $+/-1$, the closer to a perfect linear relationship. This is how the corrections are interpreted..- -1.0 to -0.7 strong negative association, -0.7 to -0.3 weak negative association, -0.3 to +0.3 little or no association, +0.3 to +0.7 weak positive association, and +0.7 to +1.0 strong positive association. (Simon, 2005), While -1 indicates a perfect inverse linear relationship, that is y increases u uniformly together. A value of 0 indicates no relationship; in positive relationships as x increases y also increases (DeCaro, 2003).

\section{Data Analysis And Presentation}

\subsection{Introduction}

This chapter presents analysis of the data on factors affecting the implementation of health and safety measures in supermarkets in Kenya. The study was conducted on supermarkets because they constitute a big Percentage as employers making them suitable for the study.

\subsection{Response Rate}

The study's target population was 18 human resource department staff. However, only 14 questionnaires were returned duly filled in, this makes a response rate of $77.8 \%$. This response rate is acceptable and representative and conforms to Mugenda and Mugenda (1999) stipulation that a response rate of $50 \%$ is adequate for analysis and reporting; a rate of $60 \%$ is good and a response rate of $70 \%$ and over is excellent.

\subsection{Reliability test}

Table 4.1 below illustrates the results of reliability analysis. Reliability of the scale for the constructs describing the variables of the study was found to be sufficient since a constructive composite reliability coefficient of 0.6 and above was realized and considered adequate (Mugenda and Mugenda, 2003). Reliability evaluates accuracy of the measures through assessing the internal stability and consistency of items in each variable (Sekaran, 2003). It can thus be concluded that the measures have an acceptable level of reliability. 


\section{Table 4.1: Reliability Statistics}

\begin{tabular}{lll}
\hline Variable & Cronbach's Alpha & N of Items \\
\hline Leadership & .770 & 4 \\
Employee participation & .659 & 3 \\
\hline
\end{tabular}

\subsection{Demographic Information of the Respondents}

According to the findings, the supermarkets that were surveyed were; Maguna Andu, Naivas, Tuskys, Uchumi and Ukwala.

\subsubsection{Position in the organization}

The study sought to establish the positions held by the respondents in their respective supermarkets. According to the table 4.2 below, $64.3 \%$ were human resource managers while $35.7 \%$ were operations resource managers.

Table 4.2: Position in the organization

\begin{tabular}{llll}
\hline & Frequency & Percentage \\
\hline Human Resource Manager & 9 & 64.3 \\
Operations & Resource Manager & 5 & 35.7 \\
Total & & $\mathbf{1 4}$ & $\mathbf{1 0 0 . 0}$ \\
\hline
\end{tabular}

\subsubsection{Gender of the Respondents}

According to the Figure 4.1 below, $64.3 \%$ were males while $35.7 \%$ were females. This shows that, the supermarkets had more males in the human resource department than females meaning that male are better suited for the job than females So most supermarkets employed middle aged persons, who are mature and better suited for the job.

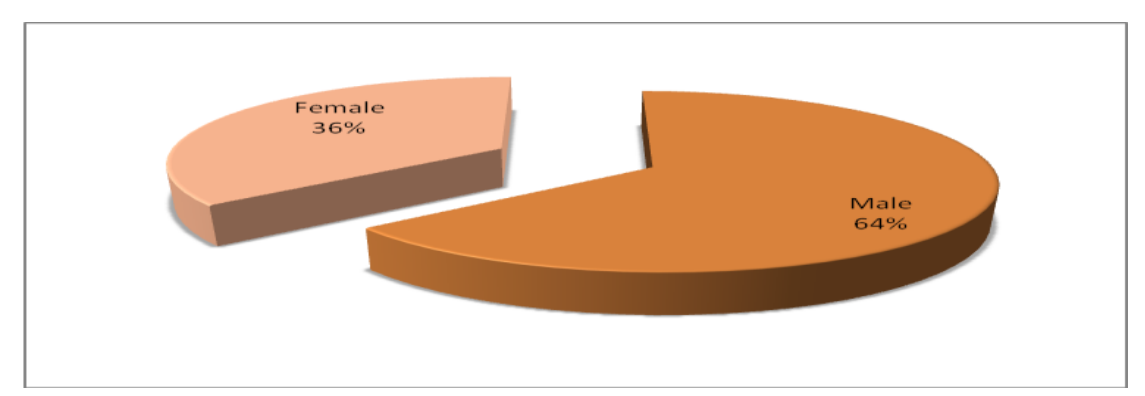




\section{Macrothink

\section{Figure 4.1: Gender of the respondents}

\subsubsection{Age of the respondents}

According to figure 4.2 below majority of the respondents were aged between 31 and 45 years, $21.4 \%$ were aged between 46 and 50 years, while $14.3 \%$ were aged below 30 years. It therefore shows that majority of the respondents were middle aged persons.

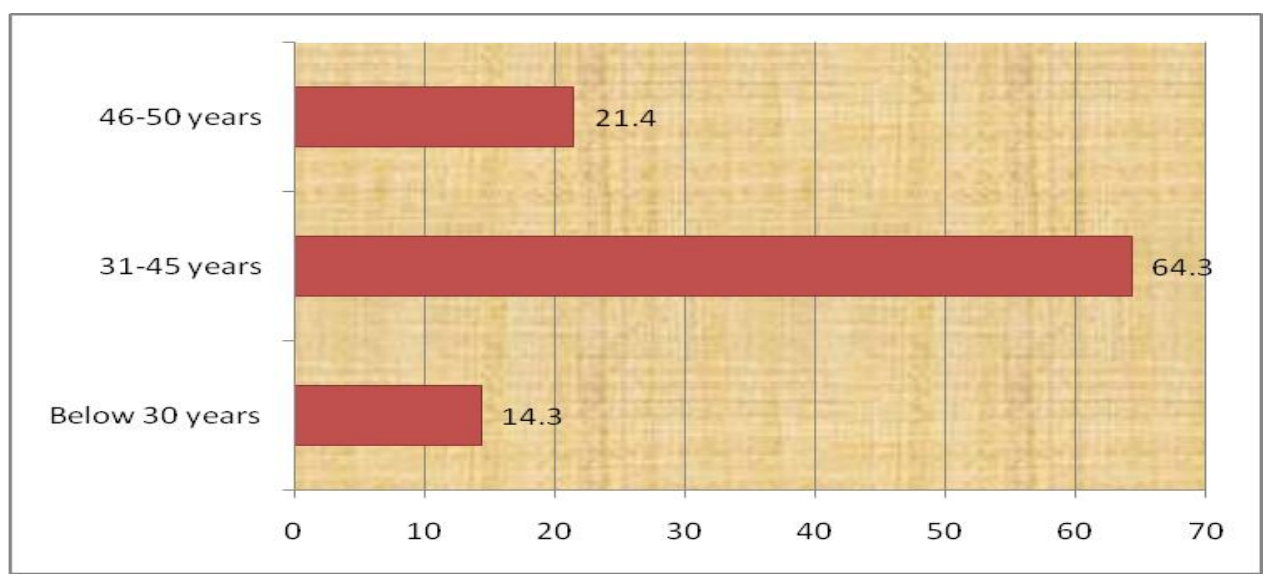

\section{Figure 4.2: Age of the Respondents}

\subsubsection{Respondents' highest level of education}

The study also required the respondents to state their highest level of education. Table 4.3 below most of the respondents (42.9\%) stated that they had their highest education as undergraduate, $35.7 \%$ stated that they had their highest education level as masters and $21.4 \%$ had college or below education as their highest level of education. This indicates that majority of the respondents had at least a degree. This indicates that they were best suited to give information as sought by the study. This is in line with Muruka (2004), who recommends that learners should access intensive induction and continuous tailor made training programmes, designed by professional curriculum developers to new and potential workers in the labour market and increased investment in the training of OHS personnel at all levels ranging from primary schools through universities should be government's objective. 
Table 4.3: Respondents' highest level of education

\section{Frequency Percentage}

College level and below $\quad 3 \quad 21.4$

Undergraduate

6

42.9

Masters Level

5

35.7

Total

14

100.0

\subsubsection{Working Duration at Supermarket}

According to the figure below, majority of the respondents $(71 \%)$ stated that they had worked in the supermarket for 3 to 6 years while few (29\%) had worked in the supermarkets for 1 to 3 years. It therefore indicates that majority of the respondents had enough experience in the supermarket and therefore were well situated to give the information as required by the study.

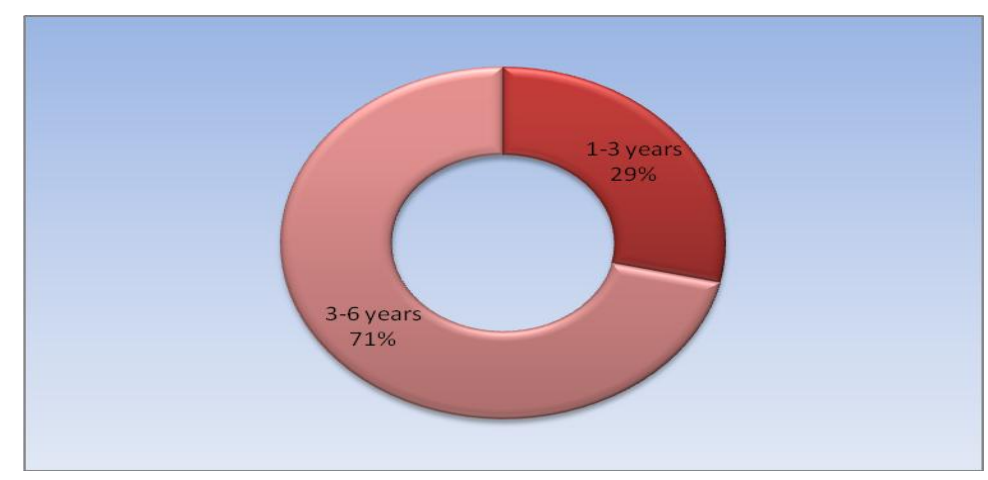

\section{Figure 4.3: Working Duration at Supermarket}

\subsection{Leadership}

The study sought to find out the frequency the supermarket management discussed safety measures. Majority $(64.3 \%)$ of the respondents stated that, the supermarket management discussed safety measures occasionally while few $(35.7 \%)$ said that their supermarkets discussed safety measures frequently.

These results are not in line with Hall ,Taylor \& Torrington (2005), who noted that the Health and Safety Regulations 1996, require employers to consult collectively and frequently with the employees about Health and Safety matters irrespective of whether a trade union is recognized. Health and Safety policies work better if senior managers set 
examples and show that they are committed to their upkeep (O'Brien, 2001). This depicts that, supermarkets' management did not discuss safety measures frequently as shown by majority of the respondents. This indicates that the level of management commitment towards safety measures was low.

Table 4.4: Frequency the supermarket management discuss safety measures

\begin{tabular}{lll}
\hline & Frequency & Percentage \\
\hline Frequently & 5 & 35.7 \\
Occasionally & 9 & 64.3 \\
Total & $\mathbf{1 4}$ & $\mathbf{1 0 0 . 0}$ \\
\hline
\end{tabular}

\subsubsection{Management Attitude towards Safety}

The study further sought to find out from the respondents the management attitude towards safety. The data findings are as shown on the figure 4.4 below. Majority (71\%) of the respondents stated that the management attitude towards safety in their supermarket was good while few (29\%) felt that the attitude was fair.

This is in line with Armstrong (2009), stated that leadership is the process of inspiring people to do their best to achieve a desired result therefore the leader therefore must be positive in all tasks they wish their staff to undertake. According to Nzuve (2007), to a large extent the attitude of the rank and file towards safety is a reflection of the attitude of their supervisors. It therefore shows that the management had a positive attitude towards safety. This implies that it was easy to reinforce safe practices and implementing a safety incentive program.

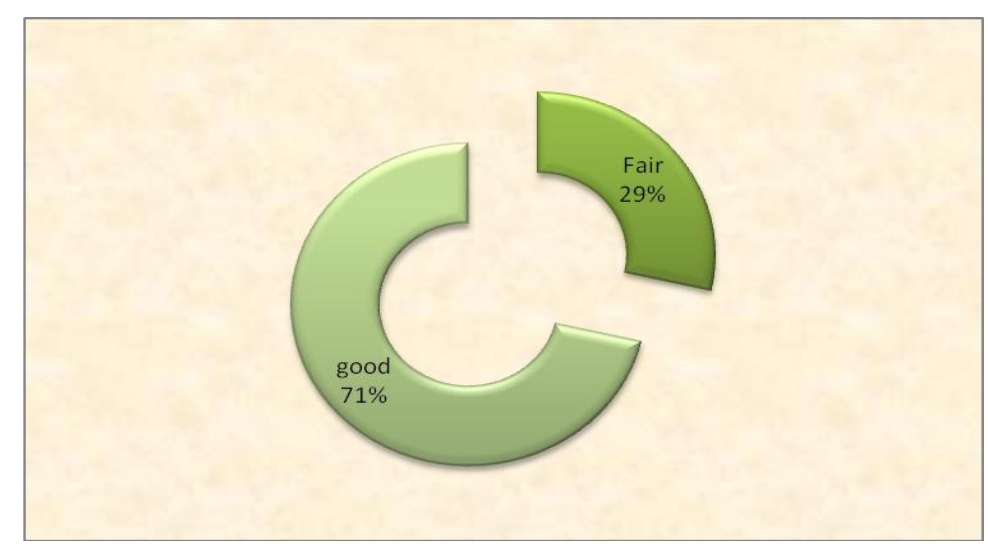

Figure 4.4 Management Attitude towards Safety 


\subsubsection{Supervision level in the supermarket}

The study further sought to find out supervision level in the supermarket, the data findings is as presented in the table 4.5 below. Majority $(64.3 \%)$ of the respondent stated that supervision in their supermarkets was high while few ( $35.7 \%$ ) were opinion that supervision was medium. The study is in line with Cullen (2002), who stated that departmentalization is one common technique to improve supervision and is aimed at reinforcing safe practices in implementing a safety incentive program to reward workers for their support and commitment to safety goals.

From the results below, supervision in the supermarkets surveyed was high. This implies that the implementation procedure would be very effective as supervision was high. Further, the study aimed at establishing whether guidance influence implementation of health and safety measures in supermarkets in Kenya. The entire respondent stated that guidance influence implementation of health and safety measures in supermarkets in Kenya.

This is because managers are responsible for ensuring that employees are conscience of health and safety hazards and do not take risks. Other respondents said that the guidance was from consultancy firms and guidance from safety and health firms. They said that this helps in compliance of the policies and that it was aimed at creating awareness and ownership of safety by staff, ensure compliance and regulatory matters are handled promptly. In the quest to find out whether the management team formulated policies to safeguard against accidents. The entire respondent said that the supermarkets management team formulated policies to safeguard against accidents. The findings were in line with Dohery \& Tyson (2000) who argue persuasively that managers are not innocent by standers with regard to employee health and wellbeing: they are involved in formulation of safety policy that aims at making the place of work safe in all aspects.

The respondents stated that this was done by ensuring that the workers wore protective clothing, in case of fire, all combustibles waste and litter were handled in a way to avoid spread of fire. They further said that communicated the need for good health and safety practice and did training in good health and safety practices. Staffs carrying out first aid training were empowered and sharing safety message. The management also provided dust coats, appointed teams to train and met on a regular basis, established reporting mechanism and response deadlines set. Regular audit are conducted to ensure prompt and exhaustive interventions are put in place. 
Table 4.5: Supervision level in the supermarket

\begin{tabular}{lll}
\hline & Frequency & Percentage \\
\hline Medium & 5 & 35.7 \\
High & 9 & 64.3 \\
Total & $\mathbf{1 4}$ & $\mathbf{1 0 0 . 0}$ \\
\hline
\end{tabular}

\subsubsection{Management team commitment toward implementing the safety measures}

On management team commitment toward implementing the safety measures, equal percentage of $50 \%$ of respondents stated that the commitment was either medium or high. This is shown on the table 4.6 below.

In showing the management's commitment Cascio, (2006), stated that management's first duty is to formulate a safety policy. Its second duty is to implement and sustain this policy through a loss control program such a program has four components; a safety budget, safety records, Managements personal concern and management's good example. To a large extent the management is seen to be committed in the implementing the safety measures. The management commitment ensures success of the implementation process.

Table 4.6: Management team commitment toward implementing the safety measures

\begin{tabular}{lll}
\hline & Frequency & Percentage \\
\hline Medium & 7 & 50.0 \\
High & 7 & 50.0 \\
Total & $\mathbf{1 4}$ & $\mathbf{1 0 0 . 0}$ \\
\hline
\end{tabular}

\subsubsection{Commitment}

The study further sought the respondents' level of agreement on the above statements concerning commitment toward implementation. The respondents were in agreement with the statements that, honesty and integrity should be followed when implementing health and safety measures as shown by a mean score of 6.0000 , flexibility and acceptability should be observed when providing guidance as shown by a mean score of 
5.6429, employees should be led with a lot of enthusiasm as shown by a mean score of 5.5000 and that results can be achieved when employees are directed as shown by a mean score of 5.3571 .

This concurs with Cascio (2006) who states that top managers can generate commitment to health and safety programmes by explaining to supervisors and others the rationale for the relevant safety and health practices. Once people understand the linkage between safety measures and the business bottom line, resistance to safety programmes should largely disappear of course, removing human resistance to any kind of programme can be difficult and delicate process that requires time and commitment (Dyck, 2002). It therefore depicts that, honesty and integrity should be followed when implementing health and safety measures, flexibility and acceptability should be observed when providing guidance, employees should be led with a lot of enthusiasm and results can be achieved when employees are directed.

Table 4.7 Commitment

\section{Mean Std. Deviation}

Results can be achieved when employees are directed 5.3571

.49725

Employees should be led with a lot of enthusiasm. $\quad 5.5000$

Honesty and integrity should be followed when implementing health and safety measures. $6.0000 \quad .00000$

Flexibility and acceptability should be observed when providing guidance

The respondents were required by the study to rate the level of leadership in the supermarket. Majority (93\%) of the respondents rated it as high, while few ( 7\% ) rated it as very high. It therefore implies that, the leadership in the supermarket is high and the respondents are satisfied with it. The study sought the respondents' opinion on how leadership can be improved in Kenyan supermarkets. The respondents said that improvement can be done by empowering the employees, leaders leading by example, follow up and being available/ reachable for consultation. They also stated that improvement of leadership can be done by the development of clear directions for the supermarkets, development of leadership programmes for supermarket and emphasis on selection of only persons with leadership potential to positions of leadership. Setting clear strategic goals and objectives which focuses on leadership, through promotion of people with leadership skills and improved communication (open communication) were also sited as other forms of improving leadership. 


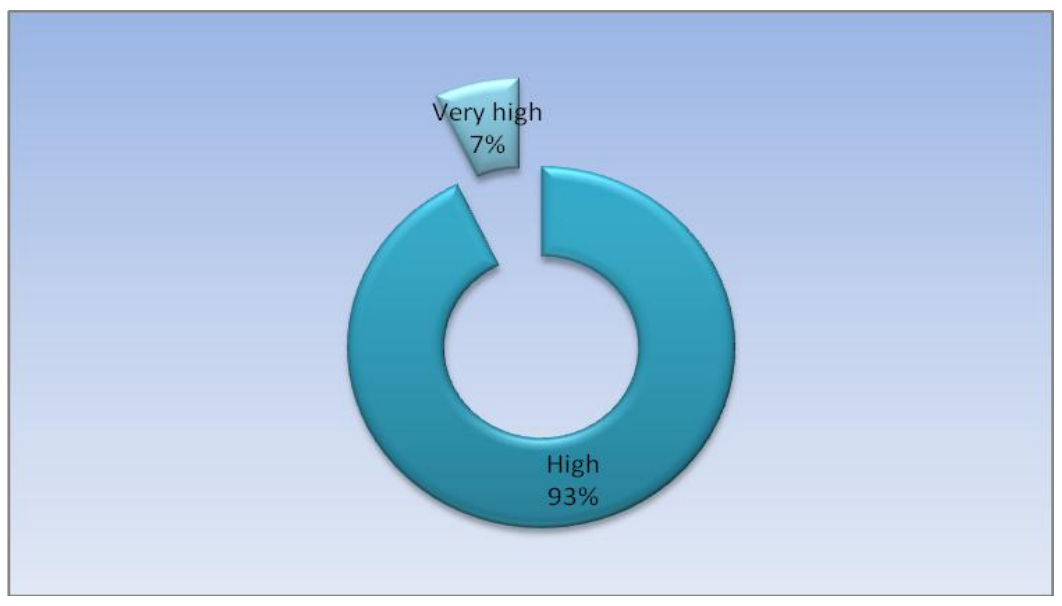

\section{Figure 4.2: Leadership in the supermarkets}

\subsection{Departments in Supermarkets.}

On how many departments were there in the supermarkets, majority $(57.1 \%)$ of the respondents stated that their supermarkets had 5 departments, while few $(21.4 \%)$ stated that had either 4 or 7 departments. This shows that the supermarket mainly have five departments as shown by majority of the respondents.

This concurs with Gerhart, Hollenbeck, Noe \& Wright (2008), safety must be considered as the responsibility of the whole organization, an attempt to departmentalize it makes the level of supervision easier for line managers, safety officials and human resource department officials. According to Mearns \& Hope (2005), through departmentalization, line managers and safety officials can exert the greater influence on health and safety. They are in immediate control and it is up to them to keep a constant watch for unsafe conditions or practices and to keep immediate action. Through departmentalization, an organization is better managed as it increases supervision. This implies, better management of supermarket surveyed.

\section{Table 4.8: Departments in the Supermarkets}

\begin{tabular}{lll}
\hline \multicolumn{1}{c}{ Departments } & Frequency & Percentage \\
\hline 4 & 3 & 21.4 \\
5 & 8 & 57.1 \\
7 & 3 & 21.4 \\
Total & $\mathbf{1 4}$ & $\mathbf{1 0 0 . 0}$ \\
\hline
\end{tabular}




\subsubsection{Departments Participation in Putting in Place Safety Measures}

Majority $(57.1 \%)$ of the respondents stated that their departments participated in putting in place safety measures while few (42.9\%) stated that their departments were not involved in putting in place safety measures. According to Dessler (2008), there are two good reasons to get involved in designing the safety Program. First, the employees are often management's best source of ideas about what the potential problems are and how to solve them. Second, employee involvement tends to encourage employees to accept the safety program.

This indicates that the supermarkets involved most of the departments in putting in place safety measures. This implies that putting in place safety measures in the supermarket is bound to succeed as a result of employee involvement. Employees are the best source of ideas about what the potential problems are and how to solve them.

Table 4.9: Departments Participation in Putting in Place Safety Measures

\begin{tabular}{lll}
\hline & Frequency & Percentage \\
\hline No & 6 & 42.9 \\
Yes & 8 & 57.1 \\
Total & $\mathbf{1 4}$ & $\mathbf{1 0 0 . 0}$ \\
\hline
\end{tabular}

\subsubsection{Employee participation and its influence on the implementation of health and safety measures}

Further the study aimed at finding out whether the employee participation influences the implementation of health and safety measures in supermarkets in Kenya. The data finding is as presented in the figure 4.6 above. Majority (64\%) of the respondents, were opinion that employee participation influences the implementation of health and safety measures in supermarkets while few (36\%), indicated that employee participation did not influences the implementation of health and safety measures in supermarkets.

The study findings concur with Price (2004), who stated that employees should be aware of aware of what constitutes safe working practices as they affect them and their fellow workers; while management and managers have the duty to communicate and train, individuals also have the duty to take account of what they have heard and learned in the ways they carry out their work. From the study results, employees' participation had an effect in health and safety measures implementation in supermarkets. 
Figure 4.3: Employee participation and its influence on the implementation of health and safety measures

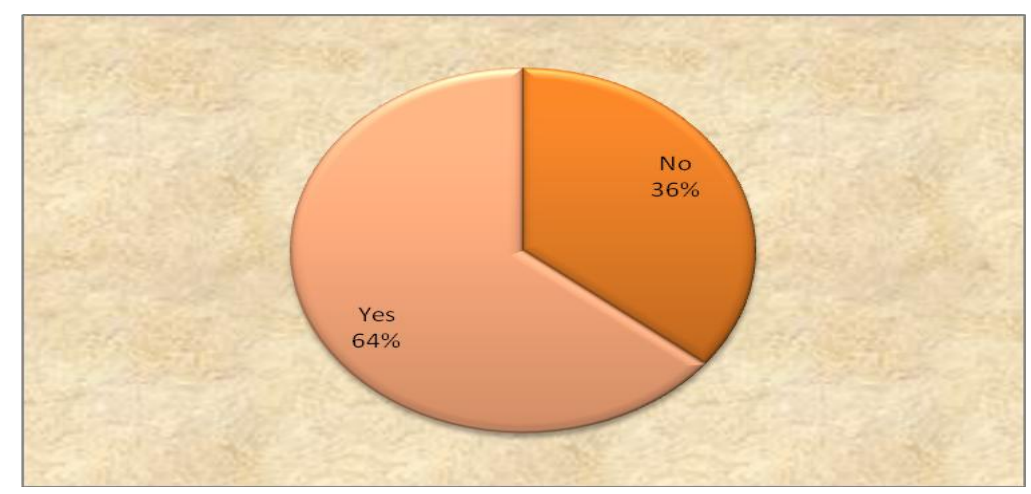

4.6.3 Extent employees' participation influence the implementation of health and safety measures

The study sought to establish from the respondents the extent employees' participation influences the implementation of health and safety measures in supermarkets in Kenya. The data finding is as presented in the figure 4.7 above. $57.1 \%$ were for the opinion that employee participation influenced the implementation of health and safety to a large extent, while few $(35.7 \%)$ felt that employees' participation influences the implementation of health and safety measures to a moderate extent while $7.1 \%$ said it influenced to a very large extent.

Reese (2003) says that employees participate in safety decisions and management should carefully consider employees suggestions for improving safety. Companies with comprehensive safety programs are likely to be rewarded with fewer accidents, fewer worker's compensation claims, and law suits and lower accidents related costs.

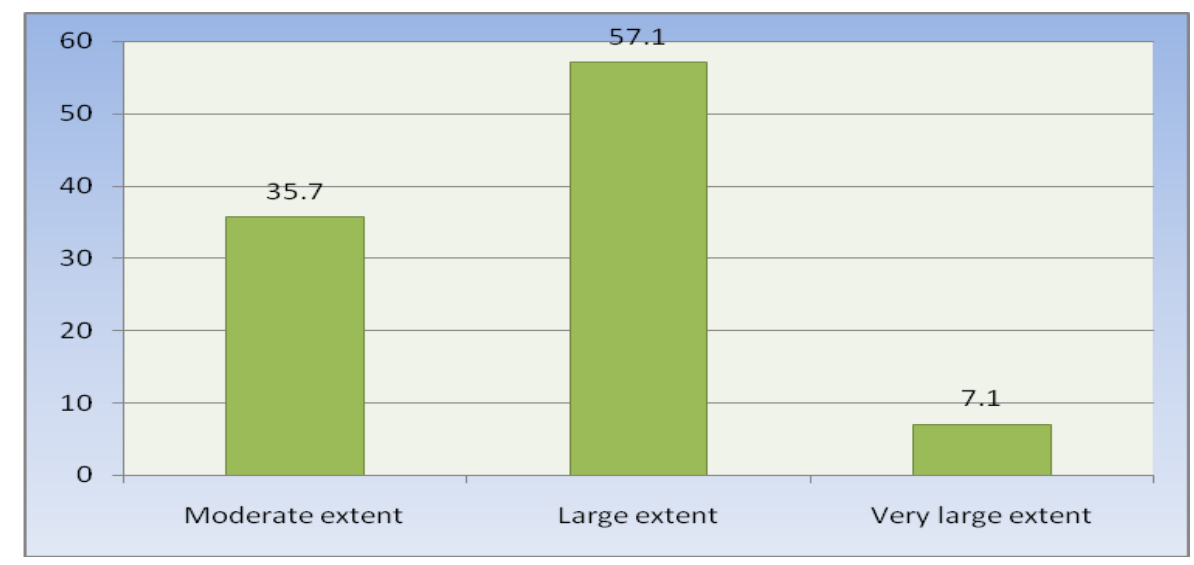

Figure 4.4: Extent employees' participation influence the implementation of health and safety measures 


\subsection{Employee participation}

The study further aimed at establishing the respondents' level of agreement on the above statements concerning commitment toward implementation. The respondents were in agreement with statements that participative approach can result in improvements on health and safety as shown by a mean score of 5.9286, it is important for managers to share information with employees as shown by a mean score of 5.9286 and that creating individualized relationships with employees on health and safety as shown by a mean score of 5.1429. They also stated that they believe in the value of providing greater autonomy to employees as shown by a mean score of 4.5714 .

According to Balkin, Cardy \& Mejia (2007) effective safety programs often include the information of a safety committee and participation by all departments within the company or organization. Top managers can generate commitment to safety and health programmes by explaining to supervisors and others the rationale for the relevant safety and health practices (Casio, 2006). It therefore shows that the participative approach can result in improvements on health and safety, it is important for managers to share information with employees, creating individualized relationships with employees on health and safety and the respondents believed in the value of providing greater autonomy to employees.

\section{Table 4.7: Employee participation}

\section{Mean Std. Deviation}

I believe in the value of providing greater autonomy to $4.5714 \quad .51355$ employees.

It is important for managers to share information with 5.9286 .26726 employees

Participative approach can result in improvements on 5.9286 .26726 health and safety.

Creating individualized relationships with employees 5.1429 on health and safety.

\subsection{Training}

The study further noted that the entire respondent had attended a course on safety measures in the supermarkets surveyed. They stated that the course was effective. According to Armstrong (2009), Health and Safety training is a key part of the preventive programme it should start as part of the induction course. It should also take 
place following a transfer to a new job or change in working methods. Safety training spells out the rules and provides information on potential hazards and how to avoid them. Further fresher training should be provided and special courses laid on to deal with new aspects of health and safety or areas in which safety problems have emerged. Safety training spells out the rules and provides information on the potential hazards and how to avoid them. The respondents had indicated that the training was effective. This shows that they were well situated in the health and safety measures implementation in their supermarkets as they had the required information for the implementation owing to their training.

Table 4.8: Length of the Training

\begin{tabular}{lll}
\hline & Frequency & Percentage \\
\hline 1 month & 4 & 28.6 \\
Others & 10 & 71.4 \\
Total & 14 & 100.0 \\
\hline
\end{tabular}

\subsubsection{Impact of lack of training on health and safety measures on performance and productivity of the employees}

The study further sought to establish the length of the training. $28.6 \%$ of the respondents stated that the training was undertaken in a month. $71.4 \%$ of them said that the training took 1 day, 3 weeks and others 5 days. The study findings does not concurs with Decenzo \& Robbins (2010), who stated that training and development need to extensive to arm the employees with the skills and knowledge to carry out their tasks in work place. The effectiveness of training is a factor of time. It therefore depicts that in supermarket the training offered was in adequate owing to the period of training. Therefore the management needs to set aside more resources to train the staff on health and safety measures.

On the extent lack of training on health and safety measures affect the performance and productivity of the employees, majority (57\%) of the respondents stated that it affected to a large extent while few ( $43 \%$ ) said that it affected to a very large extent. Cascio, (2006) noted that training and development may also include career development activities and employee counseling to help people make better choices about their careers and to achieve their desired goals. Lack of training implies therefore that the employees' goals may fail to be achieved (Hammer \&Price, 2001). It therefore indicates that, lack of training on health and safety measures affects performance and productivity of the employees to large extent. 


\section{Macrothink}

The study also sought to find out whether training influenced the implementation health and safety measures in supermarkets in Kenya. Majority (57\%), of the respondents to a large extent and few (43\%) of the respondents stated that training influenced the implementation health and safety measures. They stated that it influenced implementation health and safety measures in the following ways; reducing unsafe acts especially for new employees, enhancing awareness amongst staff and management, creates confidence in handling and preventing accidents and leads to minimization of accidents as the employees are enlightened. They further stated that the staff acquires skills and knowledge which they are able to use at the work place. They also said that it help management in formulation and implementation of policies.

Figure 4.5: Impact of lack of training on health and safety measures on performance and productivity of the employees

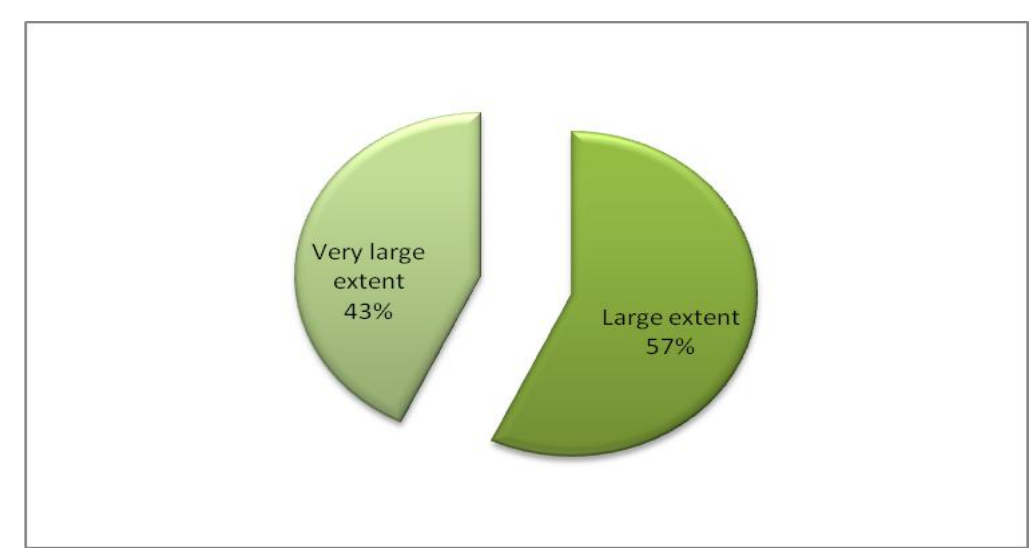

\subsection{Implementation}

The study sought to determine whether implementation of health and safety measures in Kenya's supermarkets had been felt by all stakeholders. To this query respondent had an equal opinion on their response as each side had 50\%. Further the study established that stake holders were involved in implementation of health and safety measures in supermarkets through involvement of staff, employers and customers in implementation of health and safety measure, through communicating the needs for good health and safety practices, organizing training in good health and safety practices and by providing some safety measures like fire extinguishers and fire exits.

International Labour Office, (2008) reported that major principle of OSHMS is the establishment of a line management responsibility, including the meaningful involvement of all employees at all levels in the organization, and with defined OSH responsibilities. This depicts that some of the supermarket involve their shareholders in implementation of health and safety measures while others do not. 
Figure 4.6: Involvement of stakeholders in implementation of health and safety measures

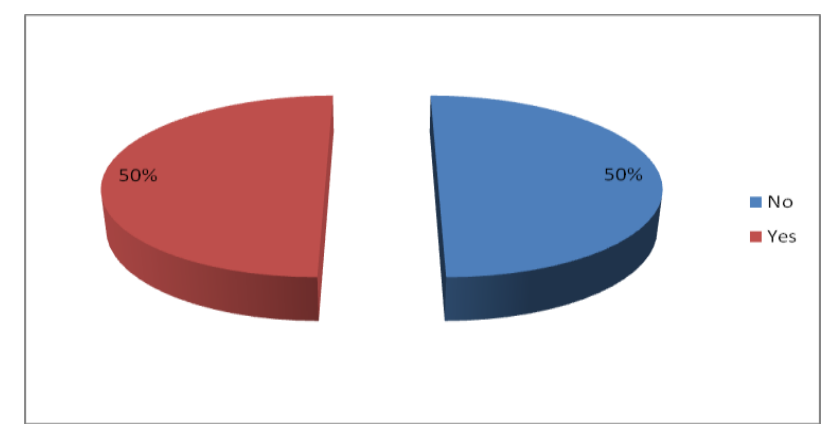

\subsubsection{Reduction of accidents in supermarkets}

The study also aimed at investigating on whether implementation of health and safety measures reduced the number of accidents that occur in our supermarkets. All (100\%) of the respondents indicated that implementation of health and safety measures had reduced occurrence of accidents in supermarkets.

According to Muchoki (2011), matters relating to occupational safety and health never used to be as prominent in the minds of most Kenyans, but, things have since changed tremendously. In relation to the findings most of the accident which were being recorded have changed as all the respondents indicates that. In relation to the below result the study requested the respondents to indicate the percentage at which implementation of health and safety measures had reduced occurrence of accidents, majority (57\%) of the respondents indicated that health and safety measures had reduced occurrence of accidents at $70 \%$ while few $(43 \%)$ indicated that health and safety measures had reduced occurrence of accidents at $80 \%$.

This was in conjunction with Bureau of labour statistics that reported that the incidence rate for cumulative trauma disorders per 10000 fulltime workers jumped from 6.3 in 1985, to 335 in 1996 (Decenzo \& Robbins,2007). According to the findings most of the supermarkets accidents had reduced above half percentage (50\%) which is quite recommendable as a result of implementation of health and safety measures. So tangible benefits from better health and safety management which include higher productivity, lower absenteeism, avoiding the costs of accidents, meeting clients demands, improved staff morale and employee relations, and so supermarkets are able to overcome the common perception that health and safety is a staff welfare issue and so use initiatives in this area of health and safety to add value to the business. 


\section{Macrothink

Table 4.9: Percentage at which health and safety measures had reduced occurrence of accidents

\begin{tabular}{lll}
\hline & Frequency & Percentage \\
\hline $70 \%$ & 8 & 57.1 \\
$80 \%$ & 6 & 42.9 \\
Total & $\mathbf{1 4}$ & $\mathbf{1 0 0 . 0}$ \\
\hline
\end{tabular}

4.9.2 Additional policy measures on health and safety be formulated and implemented

The study sought to investigate the opinion of the respondents on whether they would wish to have additional policies measure on the health and safety being formulated an implemented. All respondents $(100 \%)$ argued that they would wish to have additional policies measure on the health and safety being formulated an implemented.

This was in accordance to Khanka, (2007) who alluded that employees ignoring and even being hostile to safety and health measures. This indicates that employees are yet ready to enjoy the services that they are being offered by the supermarkets on favour of their life and health.

\subsubsection{Level of agreement on availability of the gadgets related to health and safety measures}

The table below covers the level of agreement of the respondents on the aspect on availability of the gadgets related to health and safety measures. To this query the study found that most of the supermarkets had Fire extinguishers at strategic locations, Exit points in case of fire outbreak, Employees have been trained on handling outbreaks in the supermarket and Trolleys to carry bulky goods were available and working as indicated by mean of 3.00 while Dust coats (prevent infection), Gloves and Measures to cater against theft and pilferage were not available as indicated by mean of 2.86 .

This was in line with Reese, (2003) who alluded that an ideal health program should state health and medical policy adequate health facilities according to size and nature of the organisation; such as first aid and an emergency dispensary, a registered nurse and a doctor or part time services of a doctor. This indicates that most of the supermarkets had safety and healthy facilities which effectively leads to full implementation of safety and healthy measures. 
Table 4.10: Level of agreement on availability of the gadgets related to health and safety measures

\section{Mean Std. Deviation}

Fire extinguishers at strategic locations $\quad 3.0000 \quad .00000$

Exit points in case of fire outbreak $\quad 3.0000 \quad .00000$

Employees have been trained on handling 3.0000 $\quad .00000$

outbreaks in the supermarket

Trolleys to carry bulky goods

$3.0000 \quad .00000$

Dust coats (prevent infection)

$2.8571 \quad .36314$

Gloves

$2.8571 \quad .36314$

Measures to cater against theft and 2.8571 .36314

pilferage

\subsubsection{Attitude of employee towards implementation of health and safety measure}

The study also aimed at investigating the employees altitudes towards the of health and safety measure in their respective supermarket. To this respondent had varied altitudes, majority $(85.7 \%)$ had positive altitudes stating that it saves life's and that it enhanced participation in decision making while a few $14.3 \%$ had negative attitude towards implementation of health and safety measure. This reveals that employees embrace policies implementation on health and safety measure.

Table 4.14 Attitude of employee towards implementation of health and safety measure

\begin{tabular}{lll}
\hline & Frequency & Percentage \\
\hline Positive & 12 & 85.7 \\
Negative & 2 & 14.3 \\
Total & 14 & 100 \\
\hline
\end{tabular}




\subsection{Results.}

According to DeCaro (2003), correlation is used to measure the similarity in the changes of values of interval variables but is not influenced by the units of measure. The objective of correlation analysis is to determine or establish the value and strength of relationship between any two variables. The study used Pearson correlation analysis to show whether there is a linear relationship between implementation of health and safety measures in supermarkets and nature of that relationship, if any. The results were presented in the correlation matrix below (Table 4.14).

\section{Table 4.14 Correlation Results}

\begin{tabular}{|c|c|c|c|c|c|}
\hline & & $\begin{array}{l}\text { Implement } \\
\text { ation }\end{array}$ & Leadership & $\begin{array}{l}\text { Employee } \\
\text { Participation }\end{array}$ & $\begin{array}{l}\text { Trai } \\
\text { ning }\end{array}$ \\
\hline \multirow[t]{2}{*}{ Implementation } & $\begin{array}{l}\text { Pearson } \\
\text { Correlation }\end{array}$ & 1 & & & \\
\hline & Sig. (2-tailed) & & & & \\
\hline \multirow[t]{2}{*}{ Leadership } & $\begin{array}{l}\text { Pearson } \\
\text { Correlation }\end{array}$ & .501 & 1 & & \\
\hline & Sig. (2-tailed) & .020 & & & \\
\hline \multirow[t]{2}{*}{$\begin{array}{l}\text { Employee } \\
\text { Participation }\end{array}$} & $\begin{array}{l}\text { Pearson } \\
\text { Correlation }\end{array}$ & .771 & -.289 & 1 & \\
\hline & Sig. (2-tailed) & .039 & .317 & & \\
\hline \multirow[t]{3}{*}{ Training } & $\begin{array}{l}\text { Pearson } \\
\text { Correlation }\end{array}$ & .860 & -.110 & .505 & 1 \\
\hline & Sig. (2-tailed) & .023 & .708 & .066 & \\
\hline & $\mathrm{N}$ & 14 & 14 & 14 & 14 \\
\hline
\end{tabular}

* Correlation is significant at the 0.05 level (2-tailed).

The results show that leadership had a good linear association with health and safety measures implementation given a Pearson Correlations coefficient $(\mathrm{R})$ value of 0.501 at 95.9\% significance level $(\mathrm{p}=0.020)$, Meaning that there is a moderate relationship between implementation of health and safety measures and leadership. This concurs 
with O'Brien (2001) who says that Health and Safety policies work better if senior managers set examples and show that they are committed to their upkeep .The policy will not be enforced if managers set a bad example. To avoid this they should involve staff in the health and safety process, through consultation with unions or workplace committees, ensure that employees are aware of the document and the specific contents hat applies to them for example newsletters and memoranda, visibly react to breaches of the policy (Kaplan Financial Times, 2009).

Employee participation had a coefficient of 0.771 with a p-value of 0.039 (significant at 95\% confidence level). This illustrates as high linear dependence of health and safety measures implementations on employee participation, Meaning that there is a strong relationship between implementation of health and safety measures and employee participation. Employees participate in safety decisions and management carefully considers employees suggestions for improving safety. Companies with comprehensive safety programs are likely to be rewarded with fewer accidents, fewer worker's compensation claims and lawsuits, and lower accidents related costs ( Kogi, 2002).

Training had a Pearson Coefficient of 0.860 at $95 \%$ confidence level $(\mathrm{p}=0.023)$. This depicts a very high linear dependence of health and safety measures implementation on training. This indicates that there is a strong relationship between implementation of health and safety measures and training. This is in line with Hall, Taylor \& Torrington (2005), safety training has three major purposes; employees should be told about and understand the nature of the hazards at the place of work; employees need to be aware of the safety rules and procedures; and the need to be persuaded to comply to them. These results predict that implementation of health and safety measures would be influenced positively by leadership, employee participation and training.

\section{Summary Of Findings, Conclusion And Recommendation}

\subsection{Introduction}

This chapter presents the summary of the data findings on factors affecting the implementation of health and safety measures in supermarkets in Kenya, the conclusions and recommendations drawn there to. The chapter is hence structured into summary of findings, conclusions, recommendations and area for further research.

\subsection{Summary of Findings}

The purpose of this study was to establish the factors affecting the implementation of health and safety measures in supermarkets in Kenya.

\subsubsection{Effect of Leadership on the implementation of Health and Safety Measures.}

The study found out that the supermarket discussed safety measures on occasional basis. It showed that management had a positive attitude towards safety, and that supervision in the supermarkets surveyed was high. It also found out that guidance influenced the implementation of health and safety measures in supermarkets and that supermarkets 
management team formulated policies to safeguard against accidents. The study found out that management team commitment toward implementing the safety measures to be medium.

It was established that honesty and integrity should be followed when implementing health and safety measures, flexibility and acceptability should be observed when providing guidance, employees should be led with a lot of enthusiasm and results could be achieved when employees are directed. It has further shown that the leadership in the supermarket was high.

\subsubsection{Effect of Employee Participation on the implementation of Health and Safety Measures.}

On departments' participation in putting in place safety measures, it was established that supermarkets involved most of the departments in putting in place safety measures. However it was found out the staff involvement was medium. Employee participation was shown by the study to influences the implementation of health and safety measures in supermarkets to a large extent. The study has also shown that participative approach can result in improvements on health and safety, it is important for managers to share information with employees, creating individualized relationships with employees on health and safety and the respondents believed in the value of providing greater autonomy to employees. The study also illustrates that, all the supermarkets had carried out training for its employees.

\subsubsection{Effect of Training on the implementation of Health and Safety Measures.}

The training had taken place for a period of 3 days to 1 month. Training was shown to influence the implementation health and safety measures. Lack of training on health and safety measures affects performance and productivity of the employees to large extent. It therefore depicts that in supermarkets the training offered was inadequate owing to the period of training. Therefore the management needs to set aside more resources to train the staff on Health and Safety measures. This is in line with Gupta (2006), who argues that well trained employees tend to be self reliant and motivated because they need less guidance and control; proper training can develop positive attitude among employees.

\subsubsection{Implementation of Health and Safety Measures.}

To the object of implementation and health and safety measures the study found that supermarkets equally (50\%) some involve while others does not involve their stakeholder in implementation of health and safety measures and that that stake holders were involved through involvement of staff and employers and customers in implementation of health and safety measure. The study also found that implementation of health and safety measures had reduced occurrence of accidents in supermarkets at $70 \%$ in majority of supermarkets.

Further the study found that employees wish to have additional policies measure on the 
health and safety being formulated and implemented. To the level of agreement on availability of the gadgets related to health and safety measures, the study found out that fire extinguisher at strategic locations, Exit points in case of fire outbreak were available and that employees had been trained on handling outbreaks in the supermarket. To the employees altitudes towards the of health and safety measure in their respective supermarket, the study found that employee had positive altitudes and that respondent recommended measures to be taken to manage stress among the employees to reduce accident and government to carry out health and safety audit and inspection

\subsection{Conclusion}

The study sought to establish whether leadership influences the implementation of health and safety measures in supermarkets in Kenya. To this objective the study found out that leadership influences the implementation of health and safety measures. The management teams were commitment toward implementing the safety measures.

On whether employee training influences the implementation of health and safety measures in supermarkets on Kenya, the study concluded that training influences the implementation health and safety measures. Lack of training on health and safety measures affects performance and productivity of the employees to a large extent.

The study concluded that Employee participation was shown by the study to influences the implementation of health and safety measures in supermarkets to a large extent. Participative approach can result in improvements on health and safety, it is important for managers to share information with employees, creating individualized relationships with employees on health and safety and the respondents believed in the value of providing greater autonomy to employees.

\subsection{Recommendations}

In view of the stated findings and conclusions the study obliged the following suggestions that could deal with the implementation of health and safety measures in supermarkets. They include the following:

1) The supermarkets need to improve on employee participation on health and safety measures .there are two good reasons to get the employees involved in designing the safety programs, first, employees are often managements best source of ideas about what the potential problems are and how to solve them. Second, employee involvement tends to encourage employees to accept the safety programmes. OSHA protects each employee from discrimination for exercising his or her disclosure rights. OSHA rules require employee involvement in OSHA'S on site consultation, and that employees be informed of the inspection results.

2) The supermarkets need to look into reducing unsafe acts through training .safety training is another way to reduce unsafe acts, especially for new employees. The 
Human Resource Managers should instruct new employees on in safe practices and procedures, warn them of the potential hazards, and work on developing a safety conscious attitude. The employer cannot just provide training and assume it will be effective; they must show that employees learned what to do.

3) Top management and other stakeholders should be personally involved in safety activities, give safety matters high priority in meetings and production scheduling: give the company's safety officer high rank and status: and include safety training in new worker's training. In addition top management (usually through the human resource department) should :

i) Institutionalize management's commitment with a safety policy.

ii) Publicize it; analyze the number of accidents and safety incidents and then specific achievable safety goals.

4) To the recommendation of the respondents on implementation of health and safety measures, the respondent recommended that measures to be taken to manage stress among the employees to reduce accident, government to carry out health and safety audit and inspection, training to be conducted to prevent the occurrence of accidents and implementing occupational health programmes designed by international labor organization. Other recommended that health and safety awareness to customers be conducted, inspection and compliance, networking with service providers, information sharing expansion of health and safety measures to the public and even in school, greater emphasis and subsidization of health and safety training by the government, increased joint consultative safety and health communities involving union and government and frequency in training on health and safety measures and installation of fire extinguishers in accessible areas be availed.

\subsection{Further Research.}

The study confined itself to the supermarkets in Kenya. This research therefore should be replicated in small enterprises which have a unique challenge when it comes to managing safety without Human Resource or safety departments; they often don't where to turn for advice on promoting employee safety. Many even have the inaccurate notion that OSHA doesn't cover small firms. The results should therefore be compared so as to establish whether these factors are consistent among the business premises. This will lead to the attainment of winning the war on Occupation Health and safety in business enterprises.

\section{References}

Aamodt, G. M. (2007). Industrial /Organizational Psychology, an Applied Approach, $5^{\text {th }}$ edition. Wadsworth: Thomson .

Advertiser's Announcement. (2011,April 28).World day for safety and Health at Work, 
Occupational Safety and Health Management Systems: a Tool for Continual Improvements. Nairobi, The standard, Kenya's Bold Newspaper.

Armstrong, M. (2010). Armstrong's Essential Human Resource Management Practice ,a Guide to People Management, $12^{\text {th }}$ edition. London: Kogan Page.

Armstrong .M (2009), Handbook of Human Resources Management Practices, 11th edition. London :Kogan page.

Balkin, B.D., Cardy., L.C. \& Mejia.,L.R .(2007). Managing Human Resources, $5^{\text {th }}$ edition. New Delhi :Pearson education.

Bratton, J \& Gold, J .(2009). Human Resource Management Theory and Practice, 4th edition. Basingstoke : Palgrave Macmillan.

Cascio, W. F. (2006). Managing Human Resources, Productivity, Quality of Work Life, Profits, 7th edition. London: Tata McGraw Hill.

Chapman, S \& McNeill, N. (2005). Research Methods, $3^{\text {rd }}$ edition. London: Routledge.

Cooper ,D. S \& Schlinder, P. S .(2003). Business Research Methods, $8^{\text {th }}$ edition. London : Tata Mcgraw Hill.

Cullen ,J .(2002)..A job to die for; Why so Many Americans are Killed, Injured or Made III at Work and What to Do About It. Monroe: Common Courage Press.

DeCaro,S.A .(2003). A Student's Guide to the Conceptual Side of Inferential Statistics.Retrieved on 5/11/2011,from http://psychology.sdecnet.com/stathelp.htm.

Dessler ,G. (2008).Human Resource Management,11th edition. New Delhi : Prentice Hall Inc.

Dohery,N. \& Tyson,S. (2000). Human Resource Management and Employee Wellbeing:Raising the Ethical Stakes in D.Winstanley and J.Woodall (eds) Ethical Issues in Contemporary Human Resource Management. Basingstoke: Palgrave Macmillan.

Dyck,E. D .(2002). Disability Management: Theory, Strategy and Industrial Practice, $2^{\text {nd }}$ edition. Markham Ontario: Butterworths.

Easter, K., Hegney,R \&\& Taylor,G .(2004). Enhancing Occupational Health \& Safety. Elsevier Butterworth : Heinemann.

Gathuthi ,E.W., Kosgei ,Z.K.\& Ng'ang'a, S.I .(2009). Fundamentals of Management Research Methods. Kenya Institute of Management, Nairobi: Macmillan Kenya (publishers) ltd.

Gerhart, H., Hollenbeck,N., Noe ,C.\& Wright,M. (2008). Human Resource Managemen Gaining a Competitive Advantage, 6th edition. London : Tata 
Mc Graw Hill.

Gliem ,J.A. \& Gliem ,R.R .(2003).Calculating Interpreting , and Reporting Cronbach's Alpha Reliability Coefficient for Likert Type of Scales. Mid west Research to Practice Conference in Adult and Community Education.

Gupta ,C.B .(2006).Human Resource Management. New Delhi:Pearson Education.

Hall,L., Taylor,S .,\& Torrington, D .(2005).Human Resource Management, 6th edition, New Delhi: Prentice Hall.

Hammer ,W. \&Price,D. (2001). Occupational Health and Safety Management and Engineering, $5^{\text {th }}$ edition. New Delhi: Pearson Prentice Hall.

Hasle .P., \& Limborg J.H (2005),A review of the Literature on Preventive Occupational Health and Safety Activities in Small Enterprises. Department of Manufacturing Engineering and Management \& Technical University of Denmark .

Health and Safety Commission /Department of the environment, Transport and the region .(2000). Revitalizing Health and Safety, Strategy Statement; London: DETR.

International Labour Organization.(2011).Occupational Safety and Health Management System; A tool for Continual Improvements; World Day for Safety and Health at Work. Geneva.

International Labour Office.(2008). Fundamental Principles of Occupational Health and Safety, $2^{\text {nd }}$ edition, Geneva.

Institution of Occupational Safety and Health(IOSH).(2009).Systems in Focus; Guidance of Occupational Health and Safety; retrieved on 2011,April, 28 from http://wwwiosh.co.uk.

Kamau ,C.N \& Diaby ,S.(2008).Kenya Retail Food Sector ,Kenya's Retail sector Update, USDA foreign agricultural service GAIH report, Nairobi: Global agricultural Information Network.

Kaplan, N. (2009).Understanding People Management, Kaplan Business Books, London: Kaplan .

Kogi ,K.(2002).Work Improvements and Occupational Safety and Health Managements; Common Features and Research Needs, Industrial Health,40. $121-131$.

Kothari ,C. (2004). Research Methodology, Methods and Techniques, 2nd edition. New age international (p) limited.

Kumar ,R .(2008).Research Methodology, New Delhi: Nangia for APH publishing corporation 
Lwaki .S., Mbakaya ,L.,Omondi,J \& Onyoyo .H.A. (2000).A survey on Management Perspectives of the State of Workplace Health and Safety Practices in Kenya, Nairobi: Centre for public health research, Kenya Medical Research Institute Nairobi Kenya, Directorate of Occupational Health and Safety services ,Nairobi Kenya \& Federation of Kenya Employers, Nairobi Kenya.

Maze,L. (2009,January,29). Nakumatt Fire Tragedy, Nairobi: The African Executive.

Marija,J.N.(2008). SPSS Statistics 17.0 Guide to Data Analysis, Delhi: Prentice Hall.

Mearns,K .\& Hope ,L .(2005).Health and Wellbeing in Offshore Environment; the Management of Personal Health, Research report no.305; London: Health and Safety executive.

Maruti ,L., Waswa.M.\& Waudo .J .(2004). Health Education in Kenya: Present Perspective and Challenge, Joypet services and printers limited, Nairobi: Department of environmental Health, KU.

Muchiri,F.K. (2003). Do Occupational Health Services Really Exist in Kenya? a special focus on industry and other sectors, Nairobi: Occupational Safety and Health Profiles of Kenya.

Muchiri,M .(2011).Commerce and Industry the Publication with Business Information, Online Edition. Nairobi: Directorate of Occupational Safety and Health Services.

Mugenda, A. (2008). Social Science Research :Theory and Practice Nairobi: Kijabe printing press.

Mugenda, O.M \& Mugenda ,A.G. (2003). Research Methods, Quantitative and Qualitative Approaches, Revised edition, Nairobi : Act press.

Muruka,A.O (2004), Training of Occupational Health and Safety Personnel in East Africa: Challenges for Kenya. Joypet services and printers limited, Nairobi: Department of Environmental Health, KU.

Newstrom ,J.W .(2007).Organizational Behavior Human Behavior at Work, $12^{\text {th }}$ edition . London : Tata McGraw Hill.

Neven ,D \& Readon ,T. (2004).The Rise of Kenyan Supermarkets and Evolution of their Horticultural Product Procurement Systems. Nairobi: Development policy review 22(b),669-99.

Ngugi ,K.I. \& Nyoro .J.K. (2007) .Regoverning Markets ;Small scale Producers in Modern Agrifood Markets: Kenya, Trends in growth of modern retail And wholesale chains and related agribusiness Information Sheet,

Nairobi: Unpublished Paper.

Nzuve ,M.N.S .(2007).Management of Human Resources a Kenyan perspective, 
Revised edition; Nairobi: Basic Modern Management Consultants.

O'Brien, P.D. (2001).The Safety Officer's Concise Desk Reference; London: Lewis publishers.

Occupational Health and Safety Act .(2007), Laws of Kenya: Nairobi.Odhiambo ,C.B. (2003). Poverty in Diminishing Health and Safety,Nairobi: Afri Newsletter on Occupation Health ND Safety;13:65-66.

Kangu,M.A.,Mamati.F.W.,Onwong'a,M.M.\&Osongo,N.E.(2010). Product Management and Retail Expectations on the Sale of Consumer Goods in Kenya, Perspectives on Emerging Roles of Retailers from Supermarkets in Kisii Town,Vol.1,14 page, Nairobi: African journal of business and management (AJBUMA).

Panneerselvan, R.(2004).Research Methodology, New Delhi: Prentice Hall India .Price ,N. (2004). Human Resource Management in a Business Context, $2^{\text {nd }}$ edition. Toronto: Thomson Learning.

Reese,C.D .(2003).Occupational Health and Safety Management, a Practical Approach, Toronto: Lewis publishers.

Stamoulis,K .(2003).Rise of Supermarkets Across Africa Threatens Small Farmers: Opportunities and challenges in a changing market, Nairobi: Unpublished Research Paper.

Simon ,S (2005). Research Methodology, New Delhi: Prentice Hall India Limited.

Walters,D .(2003).Workplace Arrangements for Occupational Health and Safety in the $21^{\text {st }}$ Century, School of Social Sciences ,Cardiff University, United Kingdom.

Wahome,W .(2011, April 21). Uchumi Shareholders Upset by Delay in Relisting, Nairobi: Daily Nation newspaper.

Werther,J.R \& William,B .(1996). Human Resources and Personnel Management, 5th edition, London: Tata McGraw Hill.Inc. 


\section{APPENDIX I}

\section{LETTER OF INTRODUCTION}

\section{JOMO KENYATTA UNIVERSITY OF AGRICULTURE AND TECHNOLOGY}

Dear Sir/Madam,

\section{REF: RESEARCH ON SUPERMARKETS IN KENYA.}

I am a student at Jomo Kenyatta University of Agriculture and Technology currently pursuing Masters of Science (Human Resource Management), as a partial fulfillment of the requirement for the award of the masters' degree. I am required to carry out a research study on the factors affecting the implementation of Health and Safety measures in Supermarkets in Kenya.

This is therefore to request you kindly to fill the questionnaires so as to enable me complete the study.

The information shall be purely used for academic purposes and shall be treated with confidentiality.

Thanking you for taking time to fill the questionnaire.

Yours faithfully,

\section{KAARIA ANN GACERI}

\section{APPENDIX II}

\section{QUESTIONNAIRE}

\section{General information}

This questionnaire is intended to collect data on the factors affecting the implementation of health and safety measures in supermarkets in Kenya. The information will be used for academic purposes only.

\section{SECTION A}

1. Name of the Supermarket

2. Position in the organization (tick where appropriate)

Human Resource Manager

Operations $\square$ source Manager

3.Gender: Male

Fen 
4. What is your Age?

Below 30 years

$31-45$ years

46-50 years

Above 60 years

5.Your highest level of education

College level and below

Undergraduate

Masters Level

Phd Level

6. Number of years served in this supermarket

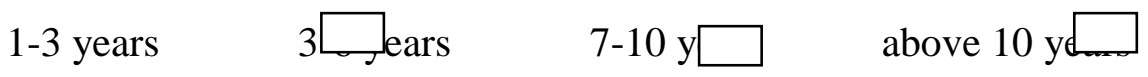

\section{SECTION B LEADERSHIP}

7. How often does the supermarket management discuss safety measures

\begin{tabular}{|l|l|l|l|l|}
\hline $\begin{array}{l}\text { Every } \\
\text { meeting }\end{array}$ & Frequently & Occasionally & Rarely & Not at all \\
\hline & & & & \\
\hline
\end{tabular}

8. What is the management attitude towards safety?

Excellent
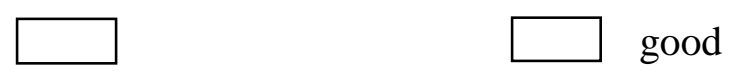

Fair
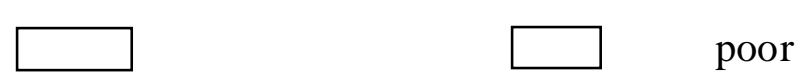

9. What is the supervision level in this supermarket?

High
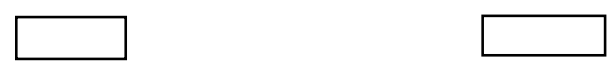

Medium

Low

10. Does guidance influence the implementation of health and safety measures in supermarkets in Kenya?

Yes
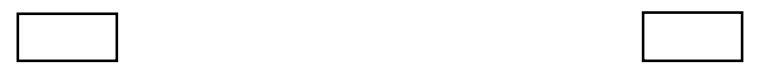

No

If yes explain 
11. Has the management team formulated policies to safeguard against accidents?

Yes

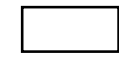

$\begin{array}{ll}\square & \text { No }\end{array}$

If

yes

outline

them

12. How can you rate the commitment of the management team toward implementing the safety measures
High

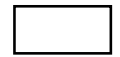
Medium
Low
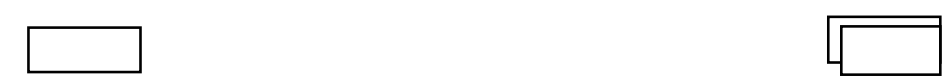
Don't know

13. Tick your level of agreement to the following commitment

\begin{tabular}{|l|l|l|l|l|l|l|}
\hline Strongly & Agree & $\begin{array}{l}\text { Slightly } \\
\text { agree }\end{array}$ & $\begin{array}{l}\text { Strongly } \\
\text { disagree }\end{array}$ & Disagree & $\begin{array}{l}\text { Unde } \\
\text { cided }\end{array}$ \\
\hline $\begin{array}{l}\text { Results can be } \\
\text { achieved when } \\
\text { employees are } \\
\text { directed }\end{array}$ & & & & & \\
\hline $\begin{array}{l}\text { Employees bed } \\
\text { should be led } \\
\text { with a lot of } \\
\text { enthusiasm. }\end{array}$ & & & & & \\
\hline $\begin{array}{l}\text { Honesty and } \\
\text { integrity should } \\
\text { be followed when } \\
\text { implementing } \\
\text { health and safety } \\
\text { measures. }\end{array}$ & & & & & & \\
\hline $\begin{array}{l}\text { Flexibility and } \\
\text { acceptability } \\
\text { should }\end{array}$ & & & & & & \\
\hline
\end{tabular}




\begin{tabular}{|l|l|l|l|l|l|l|}
\hline $\begin{array}{l}\text { observed when } \\
\text { providing } \\
\text { guidance. }\end{array}$ & & & & & & \\
\hline
\end{tabular}

14. How do you rate leadership in your organization?

Very high

Average
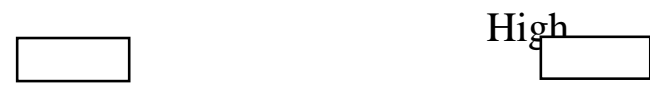

Low

15 In your own opinion how can leadership be improved in Kenyan supermarkets

\section{SECTION C EMPLOYEE PARTICIPATION}

16. How many departments does your organization have?.

17. Do all the departments participate in putting in place safety measures?

$\mathrm{Y} \square$<smiles>C1C[Te]C1</smiles>
No

18. What is the level of involvement of employees in the various departments in your organization?

High $\square$

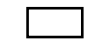

Medium

Low

19. Does employee participation influence the implementation of health and safety measures in supermarkets in Kenya?

Yes

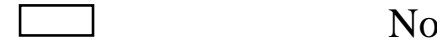

20. To what extent does employees' participation influence the implementation of health and safety measures in supermarkets in Kenya?

Very large extent

Large extent

Moderate extent

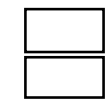

Small extent

No extent

21. Tick your level of agreement to the following statements 


\begin{tabular}{|c|c|c|c|c|c|c|}
\hline & $\begin{array}{l}\text { Strongly } \\
\text { agree }\end{array}$ & Agree & $\begin{array}{l}\text { Slightly } \\
\text { agree }\end{array}$ & $\begin{array}{l}\text { Strongly } \\
\text { disagree }\end{array}$ & disagree & $\begin{array}{l}\text { Undecide } \\
\text { d }\end{array}$ \\
\hline $\begin{array}{l}\text { I believe in the value } \\
\text { of providing greater } \\
\text { autonomy } \\
\text { employees. }\end{array}$ & & & & & & \\
\hline $\begin{array}{l}\text { It is important for } \\
\text { managers to share } \\
\text { information } \\
\text { employees }\end{array}$ & & & & & & \\
\hline $\begin{array}{l}\text { Participative } \\
\text { approach can result in } \\
\text { improvements on } \\
\text { health and safety. }\end{array}$ & & & & & & \\
\hline $\begin{array}{l}\text { Creating } \\
\text { individualized } \\
\text { relationships with } \\
\text { employees on health } \\
\text { and safety. }\end{array}$ & & & & & & \\
\hline
\end{tabular}

22. How does employee participation influence the implementation of health and safety measures in supermarkets in Kenya?

\section{SECTION D TRAINING}

23. Have you attended a course on safety measures?

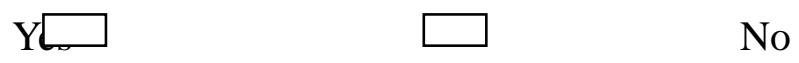

24. If yes, how effective was the course?

Very effective 


\section{Effective \\ Ineffective \\ Don't know}

25. How long was the training?

1 month $\square \quad \square$ 1 year more than a year

Others.

26. To what extent does lack of training on health and safety measures affect the performance and productivity of the employees?

Very large extent
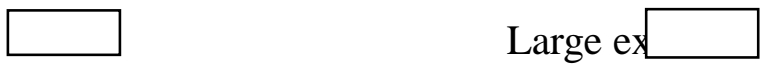

Moderate extent

No extent at all

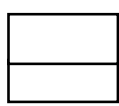

Small extent

27. Does training influence the implementation health and safety measures in supermarkets in Kenya?

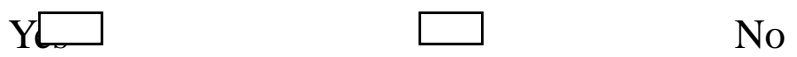

If yes how?

\section{SECTION E: IMPLEMENTATION}

28. Has implementation of health and safety measures in Kenya's supermarkets been felt by all stakeholders?

Yes

No

If yes, how

29. Has the implementation of health and safety measures reduced the number of accidents that occur in our supermarkets?

Yes
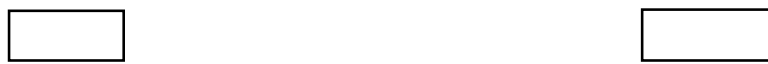

No

If yes by what percentage?

30. Would you wish in future to have more policy measures on health and safety be 
formulated and implemented?

Yes
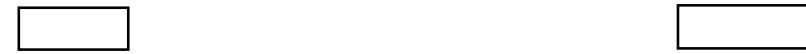

No

31. Tick your level of agreement to the availability and use of the following items in implementation of safety standards

\begin{tabular}{|l|l|l|l|}
\hline Statement & $\begin{array}{l}\text { Not } \\
\text { available }\end{array}$ & $\begin{array}{l}\text { Available and in } \\
\text { working condition }\end{array}$ & $\begin{array}{l}\text { Available but } \\
\text { not working }\end{array}$ \\
\hline $\begin{array}{l}\text { Fire extinguishers at strategic } \\
\text { locations }\end{array}$ & & & \\
\hline $\begin{array}{l}\text { Exit points in case of fire } \\
\text { outbreak }\end{array}$ & & & \\
\hline $\begin{array}{l}\text { Employees have been trained on } \\
\text { handling outbreaks in the } \\
\text { supermarket }\end{array}$ & & & \\
\hline Trolleys to carry bulky goods & & & \\
\hline Dust coats (prevent infection) & & & \\
\hline Gloves & & & \\
\hline Measures to cater against theft & & & \\
\hline
\end{tabular}

32. What are employees attitude towards implementation of health and safety measure in our Supermarkets?

33. What are some of the recommendations you would suggest to enhance implementation of health and safety measures in our supermarkets? 


\section{APPENDIX III}

\section{LIST OF SUPERMARKETS}
a) Nakumatt Holdings Limited.
b) Uchumi Supermarkets Limited.
c) Tuskys Supermarkets Limited.
d) Naivas supermarkets ltd.
e) Ukwala supermarkets ltd.
f) Magunas supermarkets 